\title{
Learning Challenges Associated with Evidence-Based Practice in Rheumatology
}

\author{
Margit Neher
}

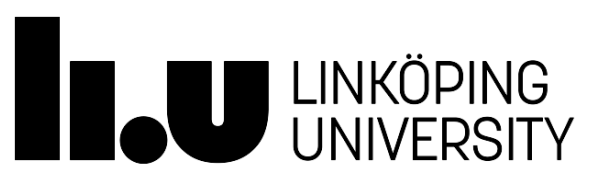

Department of Medical and Health Sciences Linköping University, Sweden Linköping 2016 
(c)Margit Neher, 2016

Cover design:

Margit Neher, Emily Tegnell, Saskia Tegnell and Annemiek Tegnell

Cover photo:

Saskia Tegnell

Published articles have been reprinted with the permission of the copyright holders.

Printed in Sweden by LiU-Tryck, Linköping, Sweden, 2016

ISBN 978-91-7685-799-1

ISSN 0345-0082 
To Robert Neher and Henny Neher-Buys

Stop and think!

(Hannah Arendt)

And let our discussions be about phronesis

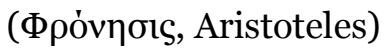



The cover of this book shows mosaics that were crafted by monks in the northern city of Luang Prabang in Laos, South-East Asia. When standing right in front of it, as I did in the beginning of this year), one can see that the wall is composed of masonry with a delicate inlay of tiny stones. Taking some steps back one sees patterns of stones forming motifs, lively scenes of people in daily life, players in a dynamic narrative whose content a relatively uninformed visitor can only guess at. Taking several more steps back, the visitor may appreciate the balance of form and colour in the building itself, with its soaring tilted and gilded roofs, of which the wall is a part.

Seeing the individual patient in clinical work may be likened to seeing the stone on the wall: uninitiated, one observes the beauty of the stone and the patterns it is a part of, and one marvels at the craftsmanship and complex cooperative efforts involved in building something so beautiful. One only has a fleeing sense of its spiritual and historical dimensions, just as I am only capable of understanding fragments of my patients and their backgrounds, and of my own clinical practice.

Matters like a stone, a wall, a house, a compound are all part of something larger, and seeing the individual part is incomplete if not understood in the bigger picture. Using our own, personal perspective is not always enough: we need to take a step back, and consider the larger picture. To understand more about the stone and the patterns on the wall, we need a guide. To understand our practice and our patients, we need other explanations and other people's experiences and knowledge to get a fuller understanding to guide our actions.

Putting together the mosaics and building stones to shape temples seems a bit similar to putting together our individual professional experiences and observations with those of others, patients, colleagues and researchers, to achieve a better clinical practice. We need both ourselves, our patients, and the combined knowledge of the many to be better informed in specific instances and to make the best decisions together. And because neither building stones nor research findings are unchanged by time and do not last forever, we need to build new temples and accept change as a part of our lives.

The studies in the thesis are a contribution to the discussion about how to meet the challenges of nurturing existing structures, but also of changing them and building new ones. 



\section{CONTENTS}

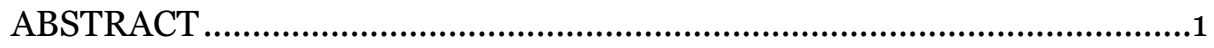

SVENSK SAMMANFATTNING ……………………........................... 3

LIST OF PAPERS …………………………………............................... 5

ACKNOWLEDGEMENTS ...................................................................... 7

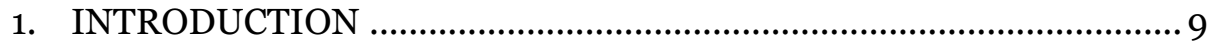

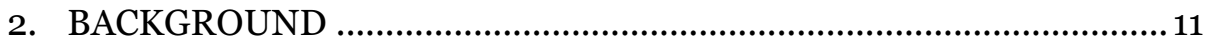

2.1. The field of rheumatology ...........................................................11

2.1.1. The field of rheumatology, setting and providers ....................... 11

2.1.2. Professionals in rheumatology.................................................. 12

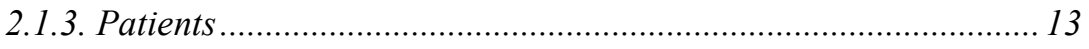

2.1.4. Developments in rheumatology ................................................ 14

2.2. Evidence-based practice and its implementation .......................15

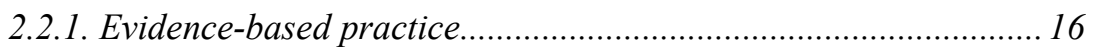

2.2.2. Conceptualizations of evidence-based practice ............................ 17

2.2.3. Controversies around evidence-based practice ........................... 18

2.2.4. Implementation research ............................................................. 20

2.3. Learning .................................................................................. 23

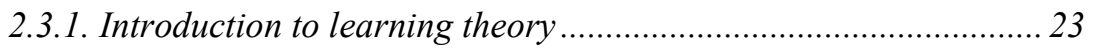

2.3.2. Cognitive perspectives of learning .............................................. 23

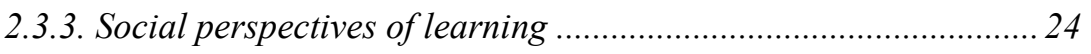

2.3.4. Behavioural perspectives of learning ........................................... 25

2.3.5. Socio-cultural perspectives of learning......................................... 25

2.3.6. Organizational perspectives of learning ...................................... 26

2.4. Use of theory and concepts in the thesis...................................28

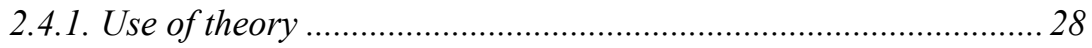

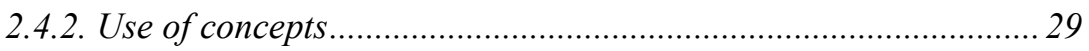




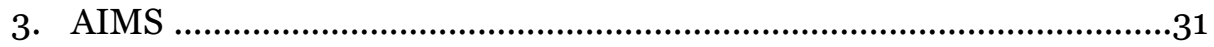

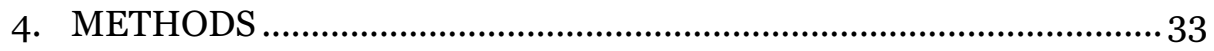

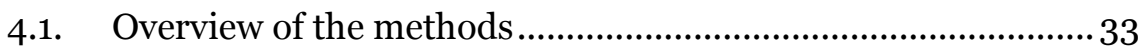

4.2. Study settings and study participants.......................................... 34

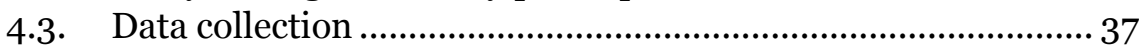

4.4. Data analysis ............................................................................. 40

4.5. Ethical considerations .............................................................. 42

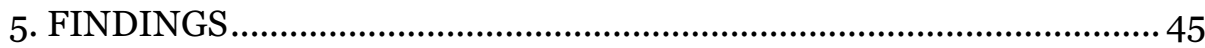

5.1. Findings in study A................................................................. 45

5.2. Findings in study B ..................................................................46

5.3. Findings in study C............................................................... 49

5.4. Findings in study D ............................................................. 52

5.5. Summary of findings .............................................................. 53

6. DISCUSSION ……............................................................................ 55

6.1. Social aspects of learning and evidence-based practice............ 55

6.2. Contextual aspects of learning and evidence-based practice... 56

6.3. Individual aspects of learning and evidence-based practice.... 58

6.4. Future studies .........................................................................60

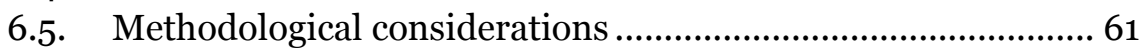

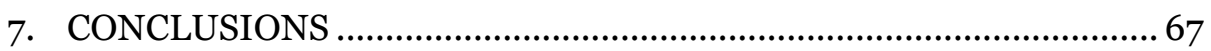

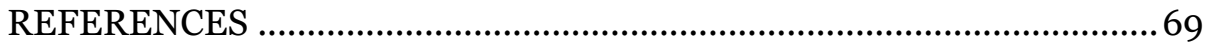

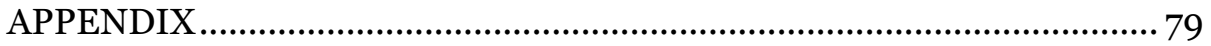




\section{ABSTRACT}

Background. Rheumatology is a field of practice that is undergoing many changes, leading to growing demand for rheumatology practitioners to keep up-to-date about the research developments in their field and to implement new findings and recommendations into clinical practice. Research within implementation science has shown that there are numerous barriers to the clinical use of research-based knowledge in health care. Implementation of evidence-based practice (EBP) requires a great deal of learning on the part of practitioners. It is likely that practitioners in rheumatology face similar challenges to those in other clinical fields, but there is a paucity of research concerning the implementation of EBP in rheumatology and the learning required.

Aims. The overall aim of the research project was to generate knowledge concerning the learning challenges associated with evidence-based practice in rheumatology.

Methods. Qualitative methods were used to explore the use of knowledge sources in rheumatology nursing and the learning opportunities in clinical rheumatology for participants belonging to five professional groups. Quantitative methods sought to examine to what extent evidence-based practice was implemented in clinical rheumatology practice and which individual and organizational factors affected research use. A theory-based study analysed the learning processes associated with achieving an evidence-based practice.

Findings. Four sources of knowledge were identified for rheumatology nursing practice: interaction with other people in the workplace (peers in particular) and previous knowledge and experience were perceived as preferred sources of knowledge, while written materials and contacts outside the workplace were less privileged. Learning opportunities occurring during daily practice were perceived by participants of all professional groups to consist predominantly of interactions with professional peers in the workplace. Participants perceived a lack of recognized learning opportunities such as continuing professional education and regular participation in rheumatology-specific courses and conferences. Participants also expressed that time for reflection and up-dating knowledge was short in everyday clinical work. 
The quantitative data showed that while the general interest for EBP was high in rheumatology practice, individual interest and professional self-efficacy related to EBP varied. A longer work-experience in rheumatology, better self-efficacy concerning the use research-based knowledge and more experience from research activities were positively associated with the use of research in practice.

The theoretical analysis showed that challenges of implementing evidencebased practice concern not only the acquisition of research-based knowledge and the integration of this knowledge in practice, but also the abandonment of outdated practices.

Conclusions. In this thesis, implementation of EBP in rheumatology has been shown to be a complex issue. Social, contextual and individual aspects were found to be involved in the learning processes, the use of knowledge sources and learning opportunities, as well as in the EBP-relevant behaviours that are enacted in clinical rheumatology. The thesis hopes to contribute to a better understanding of the learning challenges in connection with the implementation of EBP in rheumatology practice. 


\section{SVENSK SAMMANFATTNING}

Bakgrund. Många förändringar sker inom reumatologi som specialitet. Praktikerna inom fältet ställs inför ständiga krav på att uppdaterar sina kunskaper inom ämnesområdet och att ta nya forskningsresultat och kliniska rekommendationer i bruk. Implementeringsvetenskaplig forskning har visat på många hinder för användning av forskningsbaserad kunskap i vardaglig praxis. Implementering av en evidensbaserad praktik (EBP) ställer stora krav på praktikers lärande. Det finns begränsad forskning kring implementering av EBP inom reumatologi.

Syfte. Avhandlingen har som övergripande syfte att generera ökad kunskap om de lärandeutmaningar som yrkesverksamma inom reumatologi möter vid implementering av EBP.

Metod. Kvalitativa metoder användes för att studera vilka kunskapskällor sjuksköterskor förlitar sig på i sin kliniska vardag och vilka lärandetillfällen som deltagare från fem olika yrkesgrupper inom reumatologisk specialistvård uppfattade som betydelsefulla för sitt yrkesutövande. I en kvantitativ studie användes en enkät för att studera i vilken utsträckning yrkesutövare inom reumatologi implementerade EBP och vilka faktorer på individuell och på organisatorisk nivå som påverkar denna implementering. I en av studierna genomfördes en teoretisk analys i syfte att undersöka vilka typer av lärande som krävs vid implementering av EBP inom hälso- och sjukvården.

Resultat. Sjuksköterskor inom reumatologi lyfte fram betydelsen av fyra kunskapskällor i sitt vardagsarbete. Av dessa uppfattades interaktioner med andra personer på arbetsplatsen (i synnerhet inom den egna professionen) och användning av personlig erfarenhet som viktigast. Skriftliga källor och kontakter utanför arbetsplatsen användes mindre. Möten med andra yrkesutövare (ofta inom den egna yrkesgruppen) på arbetsplatsen uppfattades också som det viktigaste tillfället för lärande av andra yrkesutövare. Deltagarna menade att formella lärandetillfällen såsom kurser och konferenser var sällsynta inslag i vardagsarbetet. De uttryckte också att det fanns begränsad arbetstid som kunde ägnas åt att reflektera och uppdatera sin kunskap. 
Den kvantitativa studien visade att det fanns ett stort intresse bland deltagarna för EBP. Intresset för att använda forskningsevidens och tilliten till den egna förmågan att använda forskning skiftade. Längre erfarenhet inom reumatologi, bättre tillit till sin egen förmåga att använda forskningsevidens samt erfarenhet av forskningsrelaterade aktiviteter var associerade med ett högre mått av EBP-implementering.

Den teoretiska analysen visade att både ett anpassningsinriktat och ett utvecklingsinriktat lärande behövs för att uppnå en mer EBP. De två lärandeformerna möjliggör implementering av forskningsbaserad kunskap och utmönstrning av föråldrade beteenden som inte bidrar till en EBP.

Slutsatser. Implementering av EBP är komplext. Avhandlingen visar på betydelsen av sociala, kontextuella och individuella lärandeprocesser för att åstadkomma en mer forskningsorienterad verksamhet inom reumatologi. Genom att tillämpa ett lärandeperspektiv, har denna avhandling bidragit till en större förståelse för vilka utmaningar implementering av EBP innebär, men också hur man kan möta dessa utmaningar. 


\section{LIST OF PAPERS}

Study A.

Neher M, Ståhl C, Ellström P-E, Nilsen P. Knowledge sources for evidencebased practice in rheumatology nursing. Clinical Nursing Research 2014;24(6):661-79.

Study B.

Neher M, Ståhl C, Nilsen P. Learning opportunities in rheumatology practice: a qualitative study. Journal of Workplace Learning 2015;27(4):28297 .

Study C.

Neher M, Ståhl C, Festin, K. Nilsen P. Implementation of evidence-based practice in rheumatology: what socio-demographic, social-cognitive and contextual factors influence health professionals' use of research in practice? Submitted.

Study D.

Nilsen P, Neher M, Ellström P-E, Gardner B. Implementation of evidencebased practice from a learning perspective. Worldviews on EvidenceBased Nursing 2016; in press. 


\section{ACKNOWLEDGEMENTS}

My supervisors, Per Nilsen, Christian Ståhl and Karin Festin, for making me believe in myself. You have been trusted fellow travellers on my $\mathrm{PhD}$ journey and by generously providing mental support, thoughtful comments and methodical scrutiny of many, many, many text versions (a very special thanks to you, Per!) the journey ended in a book. I hope we will continue to meet and maybe travel together in the future!

My colleagues in the Rheumatology clinic in the County Council of Östergötland in Linköping and Norrköping, whose unfailing friendship has sustained me during many years of clinical practice, especially Jane Lindstrand, Carina Faxén and Mathilda Björk. Ingrid Thyberg for supervising my first steps into the realm of scientific study.

Implementation colleagues at Linköping University: Siw Carlfjord, Kerstin Roback, Kristin Thomas, Janna Skagerström, Susanna Ågren, Barbro Krevers, Ursula Reichenpfader, Petra Dannapfel, Sara Levin and Göran Schedvin for many discussions.

Colleagues at Linköping University, Department of Medical and Health Sciences, with whom I have shared many seminars, enjoyable moments and interesting conversations. A special thanks to Marika Wenemark and Susanne Bernhardsson for expert questionnaire advice, and to Kerstin Roberg and Anna Fogelberg-Eriksson (Department of Behavioural Sciences and Learning) for their valuable feedback on the final manuscript.

Anders, my husband and best friend, for your love and support, and our wonderful three daughters Emily, Saskia and Annemiek Tegnell. All the other members of my Swedish and Dutch extended families (who enable me to feel at home in very many places in the world indeed!): you make me strong!

Friends in different countries who love music, "food and conversation", skiing and books (do you think that this book could be made into a movie?)

Last but not least: all the participants and respondents that helped inform my studies. Thank you!! 


\section{INTRODUCTION}

This thesis is about learning and conditions for learning in rheumatology practice. It also focuses on the issue of how processes of learning in clinical practice may be associated with the implementation of evidence-based practice.

The research project had its setting in health care, more specifically in the specialty of rheumatology, a field with which the author is familiar through many years of working as an occupational therapist. The thesis focuses on generic professional learning in several professions, all of which base their practice on an explicitly science-oriented education.

As rheumatology practice becomes more complex, practitioners in the field need to develop new skills and knowledge (Woolf 2007). Better research literacy skills are expected to contribute to a more evidence-based practice, and to help professionals keep abreast of the developments in their field (Bartels 2009; Pispati 2003). The implementation of research findings and guidelines for rheumatology practice is advocated at national and European levels (Dougados et al. 2004).

Research concerning the use of scientific knowledge in clinical practice has shown that professionals experience difficulties in keeping up to date within their professional fields, leading to questions concerning conditions for professional learning (Forsman et al. 2010; Nutley et al. 2007; Squires et al. 2007). It would not be unreasonable to surmise that the difficulties in keeping up to date in the professional field of rheumatology and using research in clinical practice would be similar to those experienced in other fields, but empirical research on the issue has not been extensive.

This research project refers in part to the current discussion on evidencebased practice, and specifically the use of research in practice, but has a somewhat broader scope. In studying the knowledge that practitioners experience as helpful in their daily practice, other types of knowledge also come to the forefront. The complexity of clinical practice becomes clear when the focus is on the conditions for workplace learning and the use of research-based knowledge as part of evidence-based practice. 
Through recent societal discussions concerning the need for development of clinical competencies and discussions about the importance of evidence in practice, both in health care and in general, the research project may have some relevance for a wider discussion. Placing the implementation of evidence-based practice in the wider context of workplace learning offers new perspectives for researchers, practitioners and leaders in health care. 


\section{BACKGROUND}

This chapter introduces the clinical arena of specialized rheumatology, concepts of evidence-based practice and implementation, and learning theory, and explains how theory and concepts are used in the thesis.

\subsection{The field of rheumatology}

The section aims to give some insight into the clinical practice of rheumatology, the people working in the field and the patients whose welfare is the concern of the specialty. An insight into how the specialty is shaped by developments in society and health care is also presented.

\subsubsection{The field of rheumatology, setting and providers}

Rheumatology is a field of specialized internal medicine concerned with the diagnosis and treatment of a variety of musculoskeletal and inflammatory systemic diseases (Klareskog et al. 2005). The Swedish Rheumatology Quality Register (SRQ), which was set up in 1995, is well established and has high coverage. It monitors prevalent treatment regimens and trends in medicine, care and rehabilitation. National guidelines for musculoskeletal diseases including inflammatory rheumatic diseases were developed by the National Board of Health and Welfare in 2011, and in 2015 a follow-up evaluation showed that although some differences were seen among county councils, general compliance was satisfactory (Socialstyrelsen 2016).

In Sweden, health care is decentralized to 21 county councils. In each county, one or several hospitals (depending on population density) provide secondary care for a range of health conditions, including inflammatory rheumatic disease. Most patients with these types of disease receive specialized care in their regional hospitals, some of which have a university affiliation (SRQ, 2015). Not all patients become seriously ill, and not all patients need specialized care (Deighton et al. 2009; Socialstyrelsen 2016). For example, contrary to other countries of Europe, patients with primary osteoarthritis (which constitute a large group) are not routinely treated in secondary care in Sweden.

In recent years, research has pointed to common pathological pathways linking chronic rheumatic disease and inflammatory systemic disease with 
other inflammatory processes, and in several specialist rheumatology units, new clinical and research collaborations with other specialties in internal medicine (such as dermatology, nephrology and gastrointestinal disease) have evolved; in some hospitals, this has resulted in combined wards.

The number of people working in the specialty and involved in professional groups of interest for the study was estimated to be around 1100. Fifty different work units of different sizes were identified for the purpose of the study.

\subsubsection{Professionals in rheumatology}

Many professionals work together in rheumatology to ensure a high quality of care. The thesis has focused on those professions that have an explicit scientific knowledge base, but administrators and assistant nurses and others who rely more on skill- and experience-based competencies also provide important support and care to patients and families, and to professional and inter-professional interventions. Although the medical profession has an older and more well-established scientific footing, other health care professions (social work, nursing, occupational therapy and physiotherapy) have achieved social recognition as professions (with more and more of a scientific knowledge base) in recent years (Fitzgerald and Dopson 2005a).

Within rheumatology, interdisciplinary teamwork has traditionally been well developed relative to other specialties. Physicians and nurses have collaborated closely with occupational therapists, physiotherapists and social workers with specialized knowledge and experience, using multi-disciplinary interventions directed to disabilities in terms of impairment, activity limitation and participation restriction (World Health Organization 2001).

In the era before early diagnoses, early medical intervention and the arrival of biologics, inter-professional collaboration was deemed necessary and important. With the arrival of new pharmacological treatment options, and the increasing cost of these treatments, some county councils have reduced the resources allocated to non-medical care and rehabilitation, and many clinics have seen shifts in roles and responsibilities. This has led to differences in access to rehabilitation in some parts of Sweden (Socialstyrelsen 2016). 
Although modern medication is effective in combatting inflammation and enhancing the health status of patients with rheumatic disease, expectations concerning patients' ability to work and function are also higher today (Ahlstrand et al. 2015). Nurses, the largest group of professionals in rheumatology, have been called upon to develop their professional role to support the medical profession, as physicians specialized in rheumatology are under severe pressure to meet the prescription and monitoring requirements in an increasing number of patients. Interventions in modern rehabilitation now not only aim to limit aspects of disability (such as pain and stiffness, fatigue and muscle dysfunction) but also to enhance quality of life through facilitating participation in leisure, work and family life activities that are valued by the individual. Together, the members of the interdisciplinary team also strive to promote healthy lifestyle habits.

\subsubsection{Patients}

The national association for patients in rheumatology has been operational since 1945 and is one of the biggest patient organizations in Sweden with close to 50,000 members. The association is strategically and politically active in its efforts to influence both the provision and the content of care for members at local, regional and national levels. It is engaged in educational efforts targeting both professionals and patients and supports rheumatology-related research as well as providing a digital meeting platform for patients, professionals and other stakeholders (Swedish Rheumatism Association, 2016).

Being diagnosed with a chronic disease requires the patient to not only cope with disease symptoms but also adapt to new regimes of disease monitoring, treatment and medication, and recommendations to develop new (health) behaviours. In the clinic, efforts have been made to strengthen patient participation in practice by introducing patient-friendly computerbased information support (SRQ, 2015).

Many patients with rheumatic conditions are involved in teaching and research (Ahlmén et al. 2005; de Wit et al. 2011; Verschueren and Westhovens 2011). Recent research has explored ways to include patients even more in health care planning and clinical care processes, and patient-centred care has been identified as an important approach in the care of patients with rheumatic disease (Larsson 2013). 


\subsubsection{Developments in rheumatology}

Rheumatoid arthritis (RA) is one of the most common inflammatory diseases. RA is a chronic, progressive autoimmune disease associated with inflammation principally in joints, and with concurrent restrictions in activity and participation in daily life. RA has a prevalence of 0.5 to $1 \%$ in the western hemisphere, and in Sweden about 25 per 100,000 people are diagnosed with the disease every year. Even though the disease is prevalent in all age groups, most people are diagnosed in later life (50-60 years). The disease is about three times more frequent in women than in men(Klareskog et al. 2005).

Rheumatology medical practice has undergone many changes in the last 20-30 years, with many new research findings in such areas as genetics, biological therapies and diagnostic and investigational radiology (Klareskog et al. 2005). The first discovery was that, contrary to earlier practice, disease-modifying anti-rheumatic drugs (also known as DMARDS) had a very good effect when administered early in the course of the disease rather than at later stages. In primary care, early recognition of persistent symptoms has since been recommended, with rapid referral to specialist care (Deighton et al. 2009).

A second big change was the arrival of especially potent DMARDS called biologic drugs around 2000. Although the costs of biologic drugs are 3040 times higher than for traditional DMARDS, they are more potent, and the use of these drugs has increased manifold since their introduction to the clinic. Used initially only for severe cases of refractory RA, the use of biologics is now widespread for less severe cases of RA, but also for many other rheumatic conditions, with good results. The drugs have been shown to reduce disease activity and improve quality of life (Chen et al. 2006; Nam et al. 2010). Recently, however, research has shown that the effects on RA disease progression may not be as positive as previously reported (van Vollenhoven et al. 2012; Wolfe and Michaud 2010), and some reports suggest the possibility of reaching the same results with less expensive DMARDS (Kalkan et al. 2015; Sokka et al. 2013).

The use of DMARDS in active disease continues to be important, with close monitoring of disease activity, and intervention when disease control is unsatisfactory (Socialstyrelsen 2016). Specialist teams are charged with seeing the recent onset patients promptly and following them up regularly with objective measures. Ongoing access to a team of specialists from other disciplines is recommended "to address the physical and psychosocial im- 
pact of the disease, to ensure appropriate medication, and to equip the patient with the knowledge, skills and resources to minimize the effects of the disease, in both recent onset and established rheumatoid arthritis" (Deighton et al. 2009).

In the sciences of nursing, social work, occupational therapy and physiotherapy, new research has been focusing on the development of reliable instruments to monitor body function, activity capacity and participation, and to evaluate the outcome of rehabilitation and care interventions. This research has many different foci of interest, and concerns issues such as the characteristics of team-based rehabilitation (Hagel et al. 2010), development of indicators for rehabilitation interventions (Thyberg et al. 2012), physical exercise in rheumatology (Revenäs et al. 2015) assessment of valued life activities (Björk et al. 2015), and the development of health-promoting lifestyle behaviours (Zangi et al. 2012).

Advances in medicine, rehabilitation and care promise better methods for diagnosis and treatment, but need to be implemented for their potential to be realized. Changing treatment strategies, collaborations with other specialties and new professional roles pose new challenges for those working in rheumatology. Health care professionals within the specialty can no longer rely exclusively on knowledge gathered in long-past professional training or extensive work experience. Instead, professional work today is reliant upon active and life-long learning (Dougados et al. 2004).

The changes influencing rheumatology practice also have consequences for the ways in which decisions about clinical treatments are made. This is a trend that echoes that of health care in general. In the past 30 years or so, the clinical decision-making process has been a focus of research interest.

\subsection{Evidence-based practice and its implementa- tion}

This section introduces the concept of evidence-based practice (EBP), followed by a description of two newer conceptualizations of EBP. Subsequent sections give a summary of some of the controversies around EBP, and how implementation research aspects apply to evidence-based practice "in practice". 


\subsubsection{Evidence-based practice}

The roots of evidence-based practice (EBP) lie in evidence-based medicine (EBM), which was first introduced in Toronto, Canada, at McMaster University, as a new approach to teaching the practice of medicine. It was designed to "de-emphasize intuition, unsystematic clinical experience, and pathophysiologic rationale as sufficient grounds for clinical decisions". Instead, the key argument of EBM was and is that clinical practice should be based on the most up to date and trustworthy scientific knowledge (Evidence Based Medicine Working Group 1992).

Under the generic title of "evidence-based practice" (EBP), the key concepts and principles of the EBM movement have since spread far beyond its medical origins, influencing many other fields and disciplines. Definitions of EBP usually draw on an article by Sackett et al. (1996) in which EBP is described as:

the conscientious, explicit and judicious use of current best evidence in making decisions about the care of individual patients.

In the context of clinical practice, EBP is proposed to entail the integration of knowledge from three sources: research (research-based knowledge), professional expertise (the practitioner's experience-based knowledge) and the patient's values and priorities (figure 1).

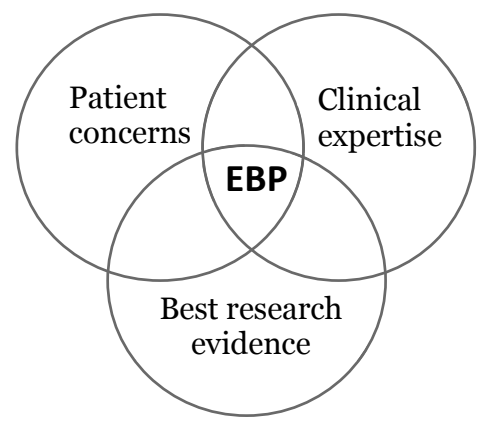

Figure 1. A common conceptualization of evidence-based practice as an interplay between three knowledge sources

In the decision-making process, the patient's values and preferences are an important in arriving at the best decision in each individual case. A patientcentred perspective is crucial in delivering appropriate care, and the role of 
the practitioner is to use his or her own expertise and knowledge in meeting the patient's expectations.

The practitioner uses two types of knowledge in clinical practice: researchbased knowledge and experience, each with their different characteristics (Nilsen et al. 2011). Research-based knowledge is often explicit, and if empirically supported, is also seen as factual (Ellström, 2010). Factual knowledge is conventionally perceived as justified, true belief, expressed as a proposition. It is formal, explicit, and empirically derived through systematic observation and experimentation. "Scientific evidence, therefore, can justify a belief as a factual claim, because the evidence is empirical, replicable, verifiable and public" (O’Brien 2006).

Experience-based knowledge is gathered by working with patients and may be difficult to communicate to others (Ellström 2010). Because this knowledge is of a personal nature, it is often bound to a certain situation and to a specific person, and often "tacit" (Eraut 2000; Polyani 1983). However, although this internalized knowledge operates instinctively and subconsciously, some parts of this "tacit" knowledge may be vocalized, and thus codified when reflected upon. Intuition, common sense and gut feelings lead to habitually performed practices (Boshoff 2014). Illeris (2011, s. 14) notes that the content of learning (i.e. the "what" of what is learned) can also encompass broader forms of knowing that relate to emotional and social factors. These and other forms of knowledge spring from personal experiences that may result from a person's actions (Dewey 1938; Kolb 1984).

In their communications with colleagues and patients, professionals need to take both types of knowledge into account when trying to reach an understanding or negotiating a plan of action to alleviate a condition or solve a problem. When integrated, these two types of knowledge will lead to the creation of new knowledge or a deeper understanding of a problem or a situation in a circular process that is of benefit to the patient or client (Dopson et al. 2005; Nilsen et al. 2011).

\subsubsection{Conceptualizations of evidence-based practice}

Recently, two different conceptualizations of EBP have been described (Olsson 2007). The different conceptualizations of EBP have led to different strategies towards the implementation of EBP in practice.

Originally, EBP was conceived as a problem-solving process (also referred to as a decision-making or a critical appraisal process) comprising five 
steps to be undertaken by the practitioner when faced with clinical uncertainty: formulating an answerable question based on a patient's problems; seeking out the best relevant evidence; critically appraising the validity and usefulness of this evidence; integrating this appraisal with practice and patient preferences; and assessing the results (Sackett et al. 1996).

Electronic sources for the retrieval of research are available to many Swedish health care practitioners. This means that evidence in the form of an answer to a clinically formulated question is often possible to access, especially with the help of library personnel. Many practitioners have learned to critically appraise evidence in their basic education, although evaluation of the potential usefulness of the evidence in practice, or the availability of some types of evidence may sometimes be more limited. These are only the first steps in the process, however, and it seems obvious that to "implement" EBP in this conceptualization, practitioners must acquire, use and become adept in numerous EBP skills. This conceptualization of EBP (carrying out all the steps of the problem-solving process in routine practice) has been recognized as suboptimal by some, because the extent to which each step is performed is determined by the patient condition encountered, by time constraints and by the level of expertise in the different EBP skills (Straus and McAlister 2000; Straus et al. 2009).

A second conceptualization of EBP has emerged in response to the challenges of realizing the EBP problem-solving process in everyday health care practice. According to this second definition, EBP can also refer to the adoption and use of various empirically supported interventions (programs, methods, services, etc.) (Midgley 2009; Olsson 2007). This view of EBP is concerned with "what works," i.e. the extent to which specific interventions have been established as effective according to some explicit criteria. Through the endeavours of networks of researchers and practitioners (e.g. Cochrane Effective Practice and Organisation of Care Group (EPOC), government agencies such as the Swedish Agency for Health Technology Assessment and Assessment of Social Services (SBU), the National Board of Health and Welfare (Socialstyrelsen) and the Swedish Association of Local Authorities and Regions (SALAR) and international organizations (e.g. World Health Organization), an increasing proliferation of guidelines with recommendations for the management of a large number of conditions are available to aid the integration of "evidence" into the decision-making process.

\subsubsection{Controversies around evidence-based practice}

As issues of effectiveness, quality, accountability and transparency gain momentum in different parts of society, science and the evidence-based 
practice movement seem to provide a measure of security, rationality and reason in an "age of anxiety" (Trinder 2000). The evidence-based movement has inspired researchers, practitioners, decision makers and other stakeholders individually, in their professional organizations and in many institutions and agencies, to intensify their support for the diffusion and dissemination of research findings. This process has been facilitated by an exponentially increasing measure of access to electronic resources, which potentially enable individuals in practically all walks of life to access research on a global scale.

Despite the availability of information, however, it has been observed that EBP is not as simple and straightforward a process as originally thought. Controversies in the field of EBP have identified problems relating to differences in understanding research evidence as a concept, and relating to how research knowledge is received and used by individuals and organizations (Bohlin and Sager 2011).

The EBP model emphasizes the importance of obtaining knowledge through empirical study, using empirical experience rather than reasoning as its most valued source of knowledge, and generating knowledge that is ideally valid, reliable and unbiased. There have, however, been some controversies surrounding the issue of EBP in practice. These issues have mostly concerned the contestable nature of knowledge and the applicability of knowledge in various situations.

One of the key problems in the EBP movement that has led to controversy is that there is no shared definition of the term "evidence" (Mullen 2014). This issue is related to the question about what types of research can supply trustworthy and acceptable knowledge? Not only is the trustworthiness of evidence connected to the passage of time, leading to (often rapid) changes in the knowledge base but the quality of evidence itself may be a problem sometimes. Poor search strategies, inclusion of biased studies and overstating of results, for example, can negatively affect the quality of systematic reviews (Järvholm and Bohlin 2014). This in turn may undermine public trust in research, affecting EBP in practice.

There is also the issue of individual acceptability. Kvernbekk (2011) proposes that evidence may be seen as the confirmation or disconfirmation of a hypothesis. A well-founded hypothesis is one that we have good reason to believe, but at the same time, personal values, commitments and experience-based beliefs may contrast sharply with research for an individual practitioner using evidence in practice. 
The fact that much research is derived from artificial contexts has been described as another reason for controversy around EBP, one that concerns efficacy versus effectiveness (Mullen 2014). Applying general knowledge (scientific and empirically derived evidence at the level of populations and groups) to particular contexts in the real world and to individual patients has been identified as challenging to the practitioner (Thorne and Sawatsky 2014). Mullen (2014) refers to this problem as a controversy about nomothetic versus ideographic knowledge.

In response to discussions around these controversies, the EBP model has evolved and so have the discussions on the implementation of EBP. The Cochrane and Campbell collaborations have developed broader evidence typologies taking into account the contextual factors to explain differences in treatment effects (Hansen 2014), and variations of the original EBP model have been proposed, including added emphasis on shared decision making and the recognition of the importance of contextual (environmental and organizational) factors (Satterfield et al. 2009).

\subsubsection{Implementation research}

As the challenges of achieving the ideals of EBM/EBP have become more recognized in the 2000s, new fields of research have evolved. The field of implementation research has grown rapidly in the wake of EBM and EBP.

Implementation in the semantic sense means, among other synonyms, "application", "execution", "enactment", "carrying out" and "putting into practice".

Implementation may take place through diffusion (a passive spread of practices), dissemination (the active spread of new practices to a target audience using planned strategies), or a combination of both. Implementation is "the process of putting to use or integrating new practices within a setting" (Brownson et al. 2012; Greenhalgh et al. 2005).

Since the middle of the 2oth century, implementation has been studied in different fields. Influential publications came from scientific fields as diverse as the sociology of agriculture, which resulted in the Theory of the Diffusion of innovations (Rogers 2003), political science research and theories around policy implementation (Pressman and Wildavsky 1973), and nursing research, which introduced theories about knowledge utilization (Weiss 1979). In recent years, the literature on research utilization, 
knowledge translation and EBP have emerged as growing subfields in the knowledge utilization literature in nursing and in other field within professional health care (Estabrooks et al. 2004; Scott-Findlay and Estabrooks 2006).

In health care, the theoretical and empirical strands of combined earlier research traditions have led to a new field of research with an interdisciplinary knowledge base, called implementation science (also referred to as implementation research or knowledge translation; others terms are also in use). Implementation science has been defined as "the scientific study of methods to promote the systematic uptake of research and other EBPs into routine practice to improve the quality and effectiveness of health services and care" (Eccles and Mittman 2006).

In implementation science, determinants are factors that are believed to, or empirically established to, affect the outcome of an implementation process. Determinants are often divided into barriers and facilitators, depending on how they influence the outcome (Per Nilsen 2015).

In a recent overview, the following set of determinants were identified (addapted from Nilsen 2015):

1. the characteristics of the method, intervention, practice, service, program, routine (the implementation object) that is introduced

2. the effectiveness of the strategy used to facilitate the implementation process, e.g. a training course for using the method

3. the characteristics of the user(s) of the implementation object, e.g. the experience and knowledge of persons participating in the training course

4. the characteristics of the end users of the implementation object, e.g. the values and motivation of the patients who will benefit from the new method

5. the characteristics of the organization or unit in which implementation occurs (usually referred to as the inner context), e.g. the professional or organizational culture in the work unit that will start using the method

6. characteristics at extra-organizational levels (typically referred to as the outer context), e.g. the wider society in which the implementation occurs 
The intended outcome of the implementation process thus emerges as a result of complex and dynamic interactions of numerous determinants that exist at different organizational levels and that change in the course of time. The determinants in the framework are more closely described and linked to one or several barriers or facilitators to implementation in a number of different theoretical frameworks (Damschroder et al. 2009; Greenhalgh et al. 2005; Grol et al. 2005). The "outcome" in implementation science signifies the impact of purposive actions to implement a method (practice, routine, innovation, etc.), and usually concerns some form of behaviour or practice change. However, defining (and measuring) outcome or "implementation success" remains "a critical yet unresolved issue in the field of implementation science” (Lewis 2015; Proctor et al. 2011). These difficulties also apply to the measurement of the use of knowledge in general, and the use of research in particular.

Many barriers have been identified regarding the implementation of EBP in routine practice (regardless of conceptualization) (Dopson et al. 2005). Despite a strong endorsement for EBP in health care, research shows that evidence-based interventions are not used routinely by health care practitioners; many continue using interventions that have little or no evidence and many rely more on their experience than on research (Gray 2009; Sigma Theta Tau International Evidence-based Practice Task Force 2004). Reflecting on the implementation of EBP in health care, Ramos-Morcillo et al. (2015) argue that integration of EBP into the clinical practice has "proceeded at a slower pace than desirable" in many health care settings.

Attitudes to research, access to information resources, education and experience in the profession have been seen to be of influence at the individual level (Squires et al. 2011a). At an organizational level, context factors such as work autonomy, organizational support and support from colleagues (e.g. leadership and work climate) have been shown to important (Gerrish and Clayton 2004; Greenhalghet al. 2005; Grol et al. 2005; Nutley et al. 2007; Squires et al. 2007). Some researchers have found that barriers to research use depend on limited skills, resources and time (Gerrish et al. 2012; Kajermo et al. 2010).

These findings have led to increased awareness of the complexity of EBP, attempts to understand its mechanisms, and a search for ways to develop strategies that could increase implementation success. Learning is considered by many implementation scientists to be of key importance for achieving a more evidence-based practice (Gray 2009; Nutley et al. 2007; Trinder 2000). 


\subsection{Learning}

In this section, a general introduction of learning theory is given followed by sections on cognitive, social, behavioural, socio-cultural and organizational perspectives of learning. The section ends with a summary of how theories and concepts are used in the thesis and a rationale for the thesis.

\subsubsection{Introduction to learning theory}

Although there is no generally accepted definition of learning, there is considerable consensus among learning theorists of both behaviourist, cognitivist, humanist, social and constructivist orientation that the experiencing of changes is inherent in the concept of learning (Merriam et al. 2007). The learning that takes place effects changes that can be expected to be more or less permanent, implying that the learner has changed from their prelearning state (Argyris and Schön 1974; Ellström 1992). Summarizing a wide range of theoretical approaches to learning, Illeris (2011) proposes that learning is "any process that in living organisms leads to permanent capacity change and which is not solely due to biological maturation or ageing”.

Learning and behaviour can be understood differently from different (cognitive, social and cultural) learning-theoretical perspectives and behaviour change theories. In recognizing that learning also has a contextual dimension and can be viewed as being part of a collective social and cultural process, many learning theorists hold that the different perspectives on learning are mutually complementary rather than competing with each other (Eraut 2007; Hodkinson and Rainbird 2006; Illeris 2011).

\subsubsection{Cognitive perspectives of learning}

In many learning theories, learning is associated with individual knowledge acquisition by individual cognitive activity. The first of two types of learning, adaptive learning, involves some kind of adaptation or a reaction to a situation, and consequently learning to handle a certain task in a routinized way. This way of learning is used when a worker becomes proficient at using a new method, task, problem or work method. Through a gradual shift from slower, deliberate behaviours, the worker's performance becomes faster, smoother and more efficient (Ellström 2001, 2006). Adaptive learning typically involves a conversion of explicit knowledge to implicit (or tacit) knowledge, a process that is termed internalization in Nonaka and 
Takeuchi's (1995) theory of learning in organizations and is described in the novice-expert theory by Dreyfus and Dreyfus (1980).

The second, developmental learning, denotes the opposite of adaptive learning: more or less automatically enacted behaviours become deliberate and conscious (Ellström 2001, 2006). Developmental learning may occur when an individual critically reflects on previously implicit assumptions and unconscious thought and action patterns. This process often involves making implicit knowledge explicit and may lead to new ways of solving complex problems. This type of learning is termed externalization by Nonaka and Takeuchi (1995) in their theory of learning in organizations.

In working life, as in daily life, both types of learning are considered to be complementary to each other and both are necessary to accomplish work and learning goals.

\subsubsection{Social perspectives of learning}

Individual cognitive activities do not happen in a vacuum, and from historical roots in social learning theory, a social-cognitive perspective of learning has developed and has gained recognition both in behavioural science and in broader popular consciousness. From the perspective of social-cognitive theory, an individual's sense of self is shaped by personal experiences, which in turn are closely connected to and influenced by the social surroundings.

The ways in which the individual tackles different everyday relationships and situations, i.e. a person's behaviour, is characterized by these personal experiences. The individual, the environment and the individual's actions influence each other in reciprocal interactions. In the process, individual learning occurs, behaviour is adapted and changes are effectuated in the environment, leading to new cycles of changes. According to this theory, a person may also be able to develop behaviours that were not personally experienced and learn to shape his or her own behaviour in a new way through observing other people. Self-regulatory mechanisms grow in individuals throughout their lifetime, and through their interactions with the environment, humans develop individual and collective agency, which shapes their goal setting. In social-cognitive theory, perceived self-efficacy is an important concept. The term designates not factual or real ability but rather the way in which an individual views his or her own personal ability. This perception is considered influential on a person's behaviour when there is uncertainty concerning the best course of action (Bandura 1997). 


\subsubsection{Behavioural perspectives of learning}

The concept of self-efficacy is only one of the factors that influence individual behaviour, according to the theoretical domains framework (TDF), which emerged from a meta-theoretical analysis of many of the most important psychology theories related to the explanation and prediction of human behaviour (Cane et al. 2012).

Based on the TDF, a theoretical model called COM_B was developed, as well as a framework for behaviour change techniques (Michie et al. 2005, 2008). The model has three components that are proposed to interact in a behaviour system to generate behaviour. Capability refers to the individual's psychological and physical capacity to engage in an activity, including the necessary knowledge and skills; opportunity is defined as all the factors outside the individual that prompt the behaviour or make it possible, and motivation is defined as the brain processes (both reflective processes, involving evaluating and planning, and automatic processes, involving emotions and impulses) that direct behaviour.

Habit theory may further contribute to our understanding of how human actions are "cued" from the environment. The process of forming habits occurs through a gradual shift in cognitive control from intentional to automatic processes. As behaviour is repeated in the same context, the control of behaviour gradually shifts from being internally guided (e.g. beliefs, attitudes and intentions) to being triggered by situational or contextual cues (Nilsen et al. 2012).

\subsubsection{Socio-cultural perspectives of learning}

Traditional views of learning have developed and expanded in the context of modern working life, and research on adult workplace learning has expanded considerably in the last 10-20 years (Fenwick 2008; Illeris 2009). Many workplace learning theorists view learning as something more than a purely individual endeavour that occurs in planned learning situations such as a course. Illeris (2011) proposes that learning is "something that takes place between people and not only in people", and that the cultural context is decisive for learning.

The concept of learning environment refers to all the opportunities for learning contained in the material and social surroundings. The concept of learning potential refers to the life of the individual as a continuous learning process. This individual potential is a result of the complex experiences of the previous life course, and is given direction by the individual's forward-looking perspectives (Illeris 2011). The individual learning trajectory 
is influenced by the interaction between characteristics of the individual learner and those of the workplace context (McKee and Eraut 2012).

In analysing the learning processes that take place in the workplace, Eraut (2007) proposes that workplace learning comprises both recognized learning processes and processes that have learning as a by-product. Recognized learning processes are described as processes whose prime objective is learning. These processes can include activities (i.e. supervision, coaching and mentoring) located at the learner's normal workplace or activities in other people's workplaces (i.e. shadowing and visiting other sites) and conferences or short courses usually outside the workplace.

Processes that have learning as a by-product include learning through experience and interactions, without a curriculum, and independently from instructor-led programs. Participation in group processes, problem solving, trying things out, consulting with others and working with clients are all processes that are central to work but also have a learning dimension (Eraut 2007).

The importance of workplace learning for acquiring and developing the skills and competencies required at work has been increasingly recognized (Conlon 2004). Marsick and Watkins (1990) concluded that four-fifths of what employees learn comes from informal workplace learning, whereas more formalized, structured training represented only one-fifth. Other estimates claim that closer to $90 \%$ of workplace learning takes place through informal means (Sohoran 1993).

Because learning occurs both through using conceptual tools for assimilating informal learning at work, and developing explicit knowledge through experience, both kinds of learning are important (Ellström and Illeris 2004). Integrating knowledge gained from formal situations (i.e. courses and other explicitly educational activities) and informal situations (such as workplace activities that stimulate learning) has been found to be meaningful both for the individual and for the organization (Svensson et al. 2004).

\subsubsection{Organizational perspectives of learning}

The context of learning has also been an issue in the fields of management and sociology. The work of Schein (2010) has highlighted the importance of leadership, organizational culture and climate through climate embedding mechanisms. 
Culture has been defined as the shared values (important and lasting ideals and preferences for certain behaviours), norms (beliefs about acceptable behaviours) and assumptions (unspoken beliefs and expectations) among members of a group, e.g. a profession (Bang 2009). Schein (2010) emphasizes the importance of unconscious taken-for-granted assumptions.

Climate is often confused with culture, but the two concepts are different. Climate is defined as the more observable, surface-level aspects of culture at a particular point in time. Ehrhart et al. (2014) defines climate as "the shared meaning organizational members attach to the events, policies, practices, and procedures they experience and the behaviors they see being rewarded, supported, and expected".

The shared values and norms of the organization are expressed in the way the work is organized and which behaviours are accepted and valued. A work (or organizational) climate may be more or less conducive to learning as a result of the way the work culture has developed in the workplace (Ellström 2010). The organizational climate that surrounds learning is considered a part of, and cannot be completely separated from, the total work environment (Karasek and Theorell 1990).

Leadership is conceived to be intimately connected to climate, and has been recognized as an important influence on implementation of EBP in many different settings (Damschroder et al. 2009; Nutley et al. 2007; RycroftMalone and Bucknall 2010). In particular, leadership commitment and active interest can positively influence implementation (Taylor et al. 2011; Stetler et al. 2011).

There is no universally agreed upon definition of leadership, but the concept is usually understood in terms of being a process whereby one person exerts intentional influence over another person or group in order to achieve a certain outcome in a group or organization (Yukl 2005). Moreover, the mechanisms through which leaders enact their influence is not clear. Although relation-oriented behaviours, task-oriented behaviours and, more rarely, change-oriented behaviours in leaders have been proposed as active ingredients in different studies, there is no general agreement on which specific behaviours leaders may enact to facilitate EBP implementation (Reichenpfader et al. 2015). 
Because of the complexity of the factors that influence organizational climate at work, researchers have grappled with difficulties in operationalizing the concept, and consequently, in investigating how organizational climate influences learning and the use of knowledge. In studies of climate, research has traditionally attempted to capture the totality of the organizational environment, but recently, new conceptualizations of the term have evolved. To focus the research effort, and to study specific components of organizational climate that are most relevant to achieve a specific outcome ("strategic climate"), measures have been developed to explicitly focus on the dimensions that are considered by experts to be of importance to the implementation of EBP. These dimensions are focus on EBP, educational support for EBP, recognition for EBP, rewards for EBP, selection for EBP, and selection for openness (Ehrhart et al. 2014).

In analogy to the reasoning about organizational climate (above), Aarons et al. (2014) propose that leadership should also be conceptualized in a narrower sense, focusing on one specific strategic imperative at a time, in this case on those behaviours in leaders that are of specific importance with regard to the adoption and use of EBP ("strategic leadership for EBP"). Informed by organizational theory, implementation theory and expert opinion, Aarons et al. (2014) propose that leadership characteristics of importance to implementing EBP are being proactive in regard to EBP implementation, possessing knowledge of EBP and implementation, providing support for EBP implementation and displaying perseverance in the EBP implementation process.

\subsection{Use of theory and concepts in the thesis}

This section clarifies how the different theoretical perspectives of learning are used and which terms and concepts are used in the different studies.

\subsubsection{Use of theory}

In the previous sections the different (cognitive, social, behavioural, sociocultural and organizational) perspectives of learning that have been applied in the thesis have been reviewed. The different perspectives have been used as theoretical frameworks and analytical tools in different studies to help design the methods, structure the data and understand the results.

In the first two studies (studies A and B), the focus was on exploring the perceptions of professionals in rheumatology concerning learning in the 
clinic. The interview guide included not only individual knowledge acquisition but also perceptions concerning contextual workplace conditions for learning, which implicitly refers to a socio-cultural perspective of learning. In the second study (study B), a typology with its explicit theory base in the field of socio-cultural learning theory was used as an analytical tool to focus the research and to structure the data.

The third study (study C) had a narrower scope in that it was designed to focus specifically on the use of research-based knowledge and the factors influencing it. The questionnaire had items based on social-cognitive theory, and instruments based on organizational theory (climate and leadership). The outcome instrument had a basis in behavioural theory, in that learning was defined as a set of behaviours that related to EBP implementation.

Study D used a combination of cognitive learning theory and behaviour theory in the discussion of learning processes involved in the implementation of EBP.

\subsubsection{Use of concepts}

As shown in previous sections, there are many conceptual understandings of learning and the use of knowledge. The use of the term EBP in particular is sometimes confusing in the literature because there are two different conceptualizations of EBP signifying either a process of critical reasoning on the one hand, or the use of knowledge "products" such as methods or guidelines on the other hand. Also, instead of taking all three parts of the EBP model into account, the term "implementation of EBP" in most cases signifies only the use of research-based knowledge in practice.

In this thesis, one part of the original EBP model (that which pertains to patient values and preferences in the clinical decision-making process) has not been studied. Instead, the aim of the project was to understand more about learning and the use of knowledge in clinical practice of professionals working in rheumatology. The first data collection had an explorative approach with aims relating to learning in a more general sense, while the second data collection and the theoretical study focused on the use of research-based knowledge (EBP in the "narrower" sense).

In studies A and B, our research aimed to explore learning in a wider sense, i.e. encompassing both "clinical expertise" (experiential knowledge) and 
"research-based knowledge". The studies focused on knowledge sources and learning opportunities related to workplace learning in rheumatology. In discussing the results of our studies, we have referred to the original EBP problem-solving model (see the description of the model in section 2.2.1).

In studies $\mathrm{C}$ and $\mathrm{D}$, the term "implementation of EBP" was synonymous with the narrower sense of the concept of EBP: "the use of research-based knowledge in practice". In study $\mathrm{C}$, we provided the participants with a short description of the original EBP model as a background to the items in the questionnaire to be as correct and clear as possible, but at the same time identified the focus of the study as the use of research-based knowledge. 


\section{AIMS}

Expectations for a more evidence-based rheumatology practice have led to a growing demand for rheumatology practitioners to keep up-to-date about the developments in their field and to implement new research findings and recommendations into clinical practice. However, research in other health care fields has shown that there are many learning challenges involved in achieving a more evidence-based practice. The same may apply to rheumatology, but research hitherto has been scarce.

The overall aim of the research project was to generate knowledge concerning the learning challenges associated with EBP in rheumatology.

The research questions that were addressed in the four studies were the following:

Study A: What perceptions do rheumatology nurses have about knowledge sources for clinical practice?

Study B: What opportunities for learning do practitioners in rheumatology perceive in their daily practice?

Study C: To what extent is EBP implemented in clinical rheumatology practice and which individual and organizational factors affect research use?

Study D: What learning processes are involved in implementing EBP in health care? 


\section{METHODS}

The following chapter provides an overview of the methods used in the studies, a summary of the study settings and participants, as well as descriptions of the methods used in the data collection, management and analysis of the qualitative and quantitative data.

\subsection{Overview of the methods}

Since the nature of the query directs what method of inquiry is appropriate, both qualitative and quantitative methods were used (Creswell 2007; Patton 2002).

The first phase of the project was concerned with exploring learning in everyday practice, particularly focusing on what perceptions practitioners in rheumatology had concerning knowledge sources for daily practice and opportunities for learning. Qualitative data were collected through in-depth interviews and provided the data for studies A and B.

The second phase aimed to investigate the extent to which EBP was implemented in clinical rheumatology practice and to identify individual and organizational factors associated with research use. Online questionnaires were distributed. The study had a quantitative approach, used statistical analysis methods, and the results are presented in study C.

The fourth study, study D, aimed to analyse the learning challenges of implementing EBP in health care. In this theoretical study, learning theory was applied to two different conceptualizations of EBP.

Table 1. Overview of the methods used in the studies.

\begin{tabular}{lllll}
\hline Study & Aim & $\begin{array}{l}\text { Participants } \\
\text { and settings }\end{array}$ & $\begin{array}{l}\text { Data } \\
\text { collection }\end{array}$ & $\begin{array}{l}\text { Method of } \\
\text { analysis }\end{array}$ \\
\hline A. & $\begin{array}{l}\text { To explore what } \\
\text { knowledge sources } \\
\text { rheumatology nurses } \\
\text { use in their practice. }\end{array}$ & $\begin{array}{l}\text { Registered } \\
\text { nurses in spe- } \\
\text { cialized rheu- } \\
\text { matology }\end{array}$ & $\begin{array}{l}\text { In-depth indi- } \\
\text { vidual inter- } \\
\text { views in par- } \\
\text { ticipants' } \\
\text { workplace }\end{array}$ & $\begin{array}{l}\text { Qualitative } \\
\text { Content Analy- } \\
\text { sis } \\
\text { (Elo \& Kyngäs, } \\
\text { 2008) }\end{array}$ \\
\hline B. & $\begin{array}{l}\text { - To explore how pro- } \\
\text { fessionals in rheuma- } \\
\text { tology perceive oppor- } \\
\text { tunities for learning in } \\
\text { daily practice }\end{array}$ & $\begin{array}{l}\text { Physicians, } \\
\text { nurses, occu- } \\
\text { pational thera- } \\
\text { pists, physio- } \\
\text { therapists and } \\
\text { vance of a typology of }\end{array}$ & $\begin{array}{l}\text { In-depth in- } \\
\text { terviews in } \\
\text { participants' } \\
\text { workplace }\end{array}$ & $\begin{array}{l}\text { Directed Quali- } \\
\text { tative Content } \\
\text { Analysis } \\
\text { (Hsieh \& Shan- } \\
\text { non, 2005) }\end{array}$ \\
\end{tabular}




\begin{tabular}{|c|c|c|c|c|}
\hline & $\begin{array}{l}\text { formal and informal } \\
\text { learning in the work- } \\
\text { place in a specialized } \\
\text { healthcare setting. }\end{array}$ & $\begin{array}{l}\text { in specialized } \\
\text { rheumatology }\end{array}$ & & \\
\hline C. & $\begin{array}{l}\text { To examine to what ex- } \\
\text { tent evidence-based } \\
\text { practice is implemented } \\
\text { in clinical rheumatol- } \\
\text { ogy practice and which } \\
\text { individual and organi- } \\
\text { zational factors affect } \\
\text { research use. }\end{array}$ & $\begin{array}{l}\text { Physicians, } \\
\text { nurses, occu- } \\
\text { pational thera- } \\
\text { pists, physio- } \\
\text { therapists and } \\
\text { social workers } \\
\text { in specialized } \\
\text { rheumatology }\end{array}$ & $\begin{array}{l}\text { Electronically } \\
\text { distributed } \\
\text { questionnaire }\end{array}$ & $\begin{array}{l}\text { Logistic regres- } \\
\text { sion }\end{array}$ \\
\hline D. & $\begin{array}{l}\text { To analyze the learning } \\
\text { challenges of imple- } \\
\text { menting EBP in } \\
\text { healthcare }\end{array}$ & Healthcare & $\begin{array}{l}\text { Discussion in } \\
\text { expert group }\end{array}$ & $\begin{array}{l}\text { Theory-based } \\
\text { study }\end{array}$ \\
\hline
\end{tabular}

\subsection{Study settings and study participants}

Study aims in the first phase of the project were to explore the perceptions of practitioners in rheumatology concerning knowledge sources and opportunities for learning in daily practice. Because of the qualitative study design, heterogeneity was sought with regard to participants' profession, educational background, experience in research activities, age and gender, years of practice in rheumatology, and size of the organization.

In-depth interviews were chosen as the data collection method. To recruit participants for the research project, an e-mail with a description of the study was sent to managers and other key persons in all the known rheumatology clinics in Sweden, including some private practices $(n=50)$. These persons were asked to send the e-mail and the project description to employees. Those employees who were interested in participating in the research project contacted the research team, and were then asked for their formal consent before starting the interview.

Eligibility criteria for participants in the first data collection were that they should belong to a professional group (physician, physiotherapist, nurse, social worker or occupational therapist) and work in specialized clinical practice with patients who had rheumatic disorders.

Interviews were conducted in 9 geographically widespread Swedish county councils, between May 2012 and February 2013. The first data collection 
resulted in study A, in which 12 nurses in nine different workplaces in different parts of Sweden participated, and study B, in which all the data from the 36 participants were analysed together. A total of 36 professionals in ten rheumatology work units participated. Five were rheumatology specialists, twelve were registered nurses, ten were physiotherapists, eight were occupational therapists, and one was a social worker. The participants, 34 women and two men, varied in age from 34 to 67 years, with an average age of 49 years. Ten of the participants had worked less than 3 years in the field of rheumatology, but others had up to 37 years of specialty experience. The participants in the sample worked in units of different sizes and locations; units were geographically widespread and located in both rural and urban areas (Table 2).

Table 2. Study participants in the first data collection $(n=36)$

$\begin{array}{lll}\begin{array}{l}\text { Work- } \\ \text { unit }\end{array} & \begin{array}{l}\text { Size of worku- Participant Profession } \\ \text { nit (no of }\end{array} & \begin{array}{l}\text { Novice/ } \\ \text { Expert }\end{array} \\ & \text { workers) }\end{array}$

\begin{tabular}{|c|c|c|c|c|}
\hline \multirow[t]{2}{*}{$\mathbf{A}$} & \multirow{2}{*}{ Large (45) } & 1 & $\mathrm{PT}$ & Expert \\
\hline & & 2 & $\mathrm{P}$ & Expert \\
\hline \multirow[t]{6}{*}{$\mathbf{B}$} & \multirow[t]{6}{*}{ Small (9) } & 3 & $\mathrm{RN}$ & Expert \\
\hline & & 4 & $\mathrm{P}$ & Expert \\
\hline & & 5 & $\mathrm{PT}$ & Expert \\
\hline & & 6 & OT & Expert \\
\hline & & 7 & OT & Novice \\
\hline & & 8 & OT & Novice \\
\hline \multirow[t]{4}{*}{$\mathbf{C}$} & \multirow[t]{4}{*}{ Small (15) } & 9 & $\mathrm{RN}$ & Novice \\
\hline & & 10 & $\mathrm{RN}$ & Novice \\
\hline & & 11 & $\mathrm{RN}$ & Novice \\
\hline & & 12 & $\mathrm{RN}$ & Expert \\
\hline \multirow[t]{3}{*}{$\mathbf{D}$} & \multirow{3}{*}{ Large (130) } & 13 & $\mathrm{RN}$ & Expert \\
\hline & & 14 & $\mathrm{RN}$ & Expert/Supervisor \\
\hline & & 15 & $\mathrm{P}$ & Expert \\
\hline \multirow[t]{3}{*}{$\mathbf{E}$} & \multirow{3}{*}{$\begin{array}{l}\text { Middle-sized } \\
\text { (30) }\end{array}$} & 16 & $\mathrm{RN}$ & Expert \\
\hline & & 17 & PT & Expert \\
\hline & & 18 & OT & Expert \\
\hline \multirow[t]{3}{*}{$\mathbf{F}$} & \multirow[t]{3}{*}{ Small (15) } & 19 & SW & Novice \\
\hline & & 20 & PT & Expert \\
\hline & & 21 & OT & Expert \\
\hline \multirow[t]{4}{*}{$\mathbf{G}$} & \multirow[t]{4}{*}{ Small (8) } & 22 & $\mathrm{p}$ & Expert \\
\hline & & 23 & $\mathrm{RN}$ & Expert \\
\hline & & 24 & OT & Expert \\
\hline & & 25 & PT & Expert \\
\hline \multirow[t]{3}{*}{$\mathbf{H}$} & \multirow{3}{*}{ Small (4) } & 26 & $\mathrm{P}$ & Expert \\
\hline & & 27 & $\mathrm{RN}$ & Novice \\
\hline & & 28 & $\mathrm{RN}$ & Expert \\
\hline \multirow[t]{4}{*}{$\mathbf{I}$} & \multirow[t]{4}{*}{ Small (10) } & 29 & OT & Expert \\
\hline & & 30 & OT & Expert \\
\hline & & 31 & $\mathrm{RN}$ & Expert \\
\hline & & 32 & $\mathrm{PT}$ & Expert \\
\hline
\end{tabular}




\begin{tabular}{lllll}
\hline & & 33 & PT & Novice \\
\hline J & Middle-sized & 34 & PT & Novice \\
\cline { 3 - 5 } & (22) & 35 & PT & Novice \\
\cline { 2 - 4 } & 36 & PT & Expert
\end{tabular}

$\mathrm{P}=$ physician, $\mathrm{RN}=$ registered nurse, $\mathrm{PT}=$ physiotherapist, $\mathrm{OT}=$ occupational therapist, $\mathrm{SW}=$ social worker. $\mathrm{E}$ =expert (more than 3 years of work-experience in rheumatology); $\mathrm{N}=$ novice (worked 3 years or less in rheumatology). Clinic size: small (2-19); middlesized (20-44), large (45+).

In the second data collection, the research aims were to estimate the extent of the implementation of EBP in rheumatology and to analyse which factors influenced that outcome using a quantitative approach. In order to answer our research questions, we wanted to gain feedback from the total population of professionals in specialized rheumatology, and chose to administer a questionnaire. It was surmised that all individuals in the target professional groups had access to the internet through their work, therefore the questionnaire was distributed online.

To cover as many work-e-mail-addresses as possible, the same managers and key persons were contacted as in the first data collection, but additionally, professional and inter-professional networks were asked to assist in the recruitment of respondents. The questionnaire was distributed in the form of a digital survey to 1168 individual e-mail addresses in 50 public and private work units. As the e-mail addresses did not correspond to actively employed individuals in $20 \%$ of cases, the study had an adjusted population of 934. The number of responders was 293, after the exclusion of one outlier. This resulted in a response rate of $32 \%$. To assess non-response bias, responders and non-responders were compared with regard to gender, age, and level of education, using Mann-Whitney and chi-square tests. There were no statistically significant differences between the groups $(\mathrm{p}<0.05)$.

Questionnaire respondents in study C consisted of 89\% women and $11 \%$ men, aged between 25 and 70 years, working in clinics of different size in all 21 county councils in Sweden. The participants belonged to five different professional groups: occupational therapists, physiotherapists, physicians, nurses and social workers (Table 3). 
Table 3: Socio-demographic characteristics of the study group in study C ( $\mathrm{n}=293)$

$\mathrm{N}(\%)$

\begin{tabular}{|c|c|c|}
\hline \multicolumn{3}{|l|}{ Sex } \\
\hline $\begin{array}{l}\text { Women } \\
\text { Men }\end{array}$ & $\begin{array}{l}254 \\
33\end{array}$ & $\begin{array}{l}(89 \%) \\
(11 \%)\end{array}$ \\
\hline \multicolumn{3}{|l|}{ Age } \\
\hline $\begin{array}{l}40 \text { years or younger } \\
41-50 \text { years } \\
51 \text { years or older }\end{array}$ & $\begin{array}{l}75 \\
83 \\
122\end{array}$ & $\begin{array}{l}(28 \%) \\
(30 \%) \\
(42 \%)\end{array}$ \\
\hline \multicolumn{3}{|l|}{ Profession } \\
\hline $\begin{array}{l}\text { Occupational therapists } \\
\text { Physiotherapists } \\
\text { Social workers } \\
\text { Physicians } \\
\text { Registered Nurses }\end{array}$ & $\begin{array}{l}57 \\
56 \\
17 \\
74 \\
89\end{array}$ & $\begin{array}{l}(20 \%) \\
(19 \%) \\
(6 \%) \\
(25 \%) \\
(30 \%)\end{array}$ \\
\hline \multicolumn{3}{|l|}{ Experience in profession } \\
\hline $\begin{array}{l}0-13 \text { years } \\
14-25 \text { years } \\
26 \text { years or more }\end{array}$ & $\begin{array}{l}85 \\
96 \\
112\end{array}$ & $\begin{array}{l}(29 \%) \\
(33 \%) \\
(38 \%)\end{array}$ \\
\hline \multicolumn{3}{|l|}{ Experience in clinical rheumatology } \\
\hline $\begin{array}{l}\text { 0-3 years } \\
\text { 4-19 years } \\
20 \text { years or more }\end{array}$ & $\begin{array}{l}65 \\
155 \\
73\end{array}$ & $\begin{array}{l}(22 \%) \\
(53 \%) \\
(25 \%)\end{array}$ \\
\hline \multicolumn{3}{|l|}{ Post-graduate education } \\
\hline $\begin{array}{l}\text { No CPE } \\
\text { Continuing Professional Education } \\
\text { Research education }\end{array}$ & $\begin{array}{l}54 \\
179 \\
43\end{array}$ & $\begin{array}{l}(20 \%) \\
(65 \%) \\
(15 \%)\end{array}$ \\
\hline \multicolumn{3}{|l|}{ Experience of research activities } \\
\hline $\begin{array}{l}\text { None } \\
\text { Active in research project }\end{array}$ & $\begin{array}{l}247 \\
46\end{array}$ & $\begin{array}{l}(84 \%) \\
(16 \%)\end{array}$ \\
\hline \multicolumn{3}{|l|}{ Number of professional peers in work group } \\
\hline $\begin{array}{l}\text { Working alone in profession } \\
\text { Small to medium work group (1-10 peers) } \\
\text { Large work group (11 peers or more) }\end{array}$ & $\begin{array}{l}30 \\
207 \\
56\end{array}$ & $\begin{array}{l}(10 \%) \\
(71 \%) \\
(19 \%)\end{array}$ \\
\hline
\end{tabular}

\subsection{Data collection}

The interview guide for the qualitative data collection was designed as a semi-structured guide with open-ended questions and wording adapted to the clinical environment. Contributions to the design of the guide were 
made by a team of researchers with diverse skills and experiences, combined with the author's familiarity with the specialty through longstanding clinical experience. The interview guide was refined by the research group through iterative and extensive discussions.

The interview guide referred explicitly to both research-based and experiential knowledge. It was left to the participants to interpret the concepts of knowledge and learning and choose which aspects they wished to focus on. Broadly, the guide covered the following areas of interest: (1) What do practitioners in rheumatology perceive as useful knowledge for daily practice? (2) Which situations do they perceive as useful for learning in daily work? (3) In what ways do they perceive that learning is supported or hindered in their workplace? (Appendix)

All the interviews were performed by the author in the workplace of the participants. Interviews were conducted one to one in almost all cases. Exceptions were made when colleagues in one workplace (and in the same profession) expressed a wish to combine the interviews. One interview was conducted with two participants, and two with three participants. All interviews took place in a room situated at the clinic, chosen by the participant. The interviews were kept to a maximum duration of 1 hour to facilitate participation during working hours. The interviews were audio-recorded and transcribed verbatim.

The questionnaire was designed to include variables that implementation research had shown to be of relevance to the research question in other contexts and to entail an acceptable workload for respondents (https://survey.liu.se/Preview/2440).

The 18-item EBP Implementation Scale was used as an outcome measure of the extent to which EBP was implemented (Melnyk et al. 2008). The instrument originates from a review of the literature on essential components and steps of EBP. The reliability and validity of the instrument was supported in a heterogeneous sample of practicing nurses, and was also translated into Norwegian (Stokke et al. 2014). Participants responded to each of the 18 items on a 5-point frequency scale by indicating how often in the past 8 weeks they performed the item. The scale ranged from o (not at all) to 4 (more than eight times). Responses to the 18 items were summed, resulting in a total score from 0 to 72. 
Five separate items were used to measure factors relating to the participants' perception of the use of research evidence in practice. The items were adapted from an instrument to assess the impact of continuing professional education (CPE) activities, based on social-cognitive theory (Légaré et al. 2015). Four of the items were scored on a scale of $1-7$, with the end points defined as low (1) and high (7). For one of the items, respondents were presented with a choice of five percentage intervals. The items could be used in any order and did not constitute a final score.

The 18-item Implementation Climate Scale was used to measure climate for EBP implementation (Ehrhart et al. 2014). The instrument captures six dimensions of the organizational context that indicate to employees the extent to which their organization prioritizes and values the successful implementation of EBPs: focus on EBP, educational support for EBP, recognition for EBP, rewards for EBP, selection for EBP, and selection for openness. Analyses of the instrument by the authors supported the reliability and construct-based evidence of validity for the Implementation Climate Scale, as well as the aggregation of the measure to the work group level. The instrument was scored on a scale of o (not at all) to 4 (to a very great extent). The total score ranged from 0 to 72 (o-12 per subscale).

The 12-item Implementation Leadership Scale was used to measure strategic leadership for implementation (Aarons et al. 2014). The instrument demonstrated excellent internal consistency and reliability as well as convergent and discriminant validity when tested by the authors. The instrument has four subscales representing proactive leadership, knowledgeable leadership, supportive leadership, and perseverant leadership. The items were scored on a scale of o (not at all) to 4 (to a very great extent). Responses to the 12 items were summed, resulting in a total score ranging from 0 to 48 .

The four instruments and five items included in the questionnaire are presented in Table 4. In addition, data were collected on the participants' age, sex, work experience and experience in rheumatology, postgraduate education, experience of research activity, their role in the clinic (e.g. clinical leadership), and the number of peers in the work group. 
Table 4. Overview of instruments and items used in the questionnaire (study C).

\begin{tabular}{|c|c|c|c|c|}
\hline Name & $\begin{array}{l}\text { No of } \\
\text { items }\end{array}$ & Scale & Score & Reference \\
\hline $\begin{array}{ll}\text { EBP } & \text { Implementation } \\
\text { Scale } & \end{array}$ & 18 & $\begin{array}{l}\text { 5-point frequency } \\
\text { scale }\end{array}$ & $0-72$ & Melnyk (2008) \\
\hline \multirow{2}{*}{$\begin{array}{l}\text { Items based on } \\
\text { Social Cognitive Theory }\end{array}$} & \multirow[t]{2}{*}{5} & 1 (low)-7 (high) & \multirow[t]{2}{*}{-} & \multirow[t]{2}{*}{ Légaré (2015) } \\
\hline & & $\begin{array}{ll}0-20 \% ; & 21-40 \% \\
41-60 \% ; & 61-80 \% ; \\
81-100 \% & \end{array}$ & & \\
\hline $\begin{array}{l}\text { Implementation } \\
\text { Climate Scale }\end{array}$ & 18 & $\begin{array}{l}\mathrm{O} \text { (not at all)- } 4 \text { (to a } \\
\text { very high extent) }\end{array}$ & $0-72$ & Ehrhart (2014) \\
\hline $\begin{array}{l}\text { Implementation } \\
\text { Leadership Scale }\end{array}$ & 12 & $\begin{array}{l}\text { o (not at all)- } 4 \text { (to a } \\
\text { very high extent) }\end{array}$ & $0-48$ & Aarons (2015) \\
\hline
\end{tabular}

Swedish versions of three instruments were developed by the authors. In this process, the research group was assisted by a native Swedish speaker who was fluent in English, and also knowledgeable in the field of research at hand. A first version of the instruments was produced through a process of forward and backward translation. Several versions of the questionnaire were then pilot tested, through cognitive interviews with members of the target groups for the study $(n=12)$. Changes were made continually to accommodate the resulting feedback in order to produce a questionnaire that had linguistic and conceptual equivalence to the original instruments as well as acceptability for participants.

The questionnaire also included a set of questions about knowledge sources for daily practice, but the data resulting from this part of the questionnaire were not analysed.

No data were collected for the theoretical study (study D).

\subsection{Data analysis}

In the qualitative data collection, interviews were transcribed verbatim, and made anonymous through removal of all identifying information. After the transcript was completed, an identification code was assigned to each transcription. 
Qualitative content analysis (QCA) was used to analyse the qualitative data. QCA is a technique for analysis of texts grounded in empirical data with explorative and descriptive research designs (Krippendorff 2004). Hsieh and Shannon (2005) define QCA as "a research method for the subjective interpretation of the content of text data through the systematic classification process of coding and identifying themes or patterns".

In study A, we aimed to derive concepts from the data, and chose to use a method of inductive QCA (Elo and Kyngäs 2008). In study B, categories from a pre-existing typology or framework were used to help focus the research question. This method is described as directed QCA (Hsieh and Shannon 2005).

The following steps were performed in the data analysis process for study A. In the first step, each of the authors repeatedly read through each interview to make sense of the data. In step 2, all the authors identified key statements and thoughts (meaning units) with reference to the participants' perception of knowledge sources. This was done through a process of open coding, using notes and headings that the members of the research group made while reading the texts. A meaning unit consisted of one or more sentences or paragraphs of a narrative/interview text. This led to a large number of headings, which were all written down to describe all aspects of the content. In step 3, meaning units were then condensed to express the essential meaning of the original text. All authors separately made lists of headings and categories using content-characteristic words, and by doing so, generated codes. In step 4, to reduce the number of codes, the first author aggregated the codes into clusters of similar content, resulting in a system of subcategories and higher order headings. In step 5, this initial analysis was subjected to critical discussion within the research group, resulting in categories. The abstraction process was continued as far as was reasonable and possible.

Study B was based on the same data collection. Our research aim concerned opportunities for learning in everyday clinical work in rheumatology. The theoretical framework that was relevant to direct our analysis was a typology of workplace learning by Eraut (2007), based on empirical investigations in diverse professional fields, including health care. The typology includes several learning opportunities in work processes with learning as a by-product and recognized learning processes (Table 5). 
The analysis began with the explorative approach described in study A (see above, step 1-5) followed by a process of mapping the categories that resulted from our data into the theoretical framework. In this way, our analysis was assisted by the existing framework but not limited by it.

In the quantitative data collection, the aims were to investigate the extent to which EBP was implemented in clinical rheumatology practice and to identify individual and organizational factors associated with research use. Data were collected through an internet survey tool, using work e-mail addresses belonging to professionals in specialized rheumatology. To ensure anonymity, all references related to participants' personal identity were removed from the data prior to transfer to the computer program that assisted in the data analysis.

Several different statistical methods were applied in study C. To validate the translations of the instruments in the study into Swedish, we analysed the internal consistency in each instrument. Descriptive statistics were used for demographic factors and to report the distribution of scores on the measures. Differences between groups of responders and non-responders regarding gender, age, and level of education were analysed by Mann-Whitney and chi-square tests. Logistic regression analyses were performed to analyse the association of the different variables on the study outcome.

Computer packages were used for the qualitative data analyses in studies A and B (NVivo 10) and the statistical analyses in study C (SPSS, version 22).

For performing the theoretical analysis in study $\mathrm{D}$, a model of two cognitive learning processes (learning modes) was used. Through iterative discussions between researchers of various backgrounds and disciplines, the dynamics of these modes of learning, adaptive and developmental learning processes, were used as lenses for the theoretical analysis of the challenges involved in two conceptualizations of the practice of EBP.

\subsection{Ethical considerations}

Ethical aspects were taken into account at all stages of the research project. During the research process this was of particular relevance for the participants in the studies, i.e. professionals in specialist rheumatology. Participants in both data collections were informed that participation in the research project was voluntary. Participants in the qualitative data collection 
were also informed that they could withdraw at any time during or after the interview.

The informants were assured that the data collected were confidential, and that individual participants and units would not be identifiable in the presentation of the study results. Steps were taken to ensure the anonymity of participants in both data collections. In the qualitative data collection, all identifying information was removed from the texts, and in the quantitative data collection, all references related to participants' personal identity were removed from the data before data analysis. The participants' contributions were also protected through assignment of an identification code. In the final presentation of the data, care was taken to ensure that the results could not be traced back to specific individuals or small groups.

The regional ethics board in Linköping approved the project, including all studies (Dnr 2012/142-31), having scrutinized detailed plans for both data collections. Written consent was obtained from all participants. 


\section{FINDINGS}

\subsection{Findings in study $A$}

The first study in the thesis (study A) explored what knowledge sources rheumatology nurses used in their clinical practice.

Four types of knowledge sources for daily clinical practice were perceived by the rheumatology nurses who participated in the interviews: interaction with others in the workplace, contacts outside the workplace, written materials, and their personal previous knowledge and experience.

Interaction with peers and physicians in the workplace was an important knowledge source for the participants. These interactions were mostly unplanned, as no time was officially allocated to them in any of the units. Physicians were perceived as highly trusted knowledge sources and important for role development. Clinical and research-related knowledge was presented through in-house lectures, mostly by resident rheumatologists but also through outreach visits by pharmaceutical companies. The nurses expressed that they did not have much knowledge about nursing research.

The nurses in the study perceived that nurse networks outside the workplace were not very well developed, and that information about meetings and conferences was lacking. The participants perceived economic constraints to be an impediment to professional postgraduate development and education outside the clinic, and that in-house education of new nurses was generally practiced.

The category of written materials consisted of sources that were accessible in the workplace in the form of printed materials. Participants consulted textbooks and internet resources sometimes, but many expressed both individual and time barriers to reading scientific papers at work.

The participants often referred to personal experience and previous knowledge as a knowledge source. Special status was given to time spent both in the specialty and in the particular workplace, as participants perceived that knowing the routines and personalities in the present workplace made working more efficient. Participants also perceived that patient narratives from previous meetings helped to build up a store of experiential knowledge. In many situations, participants perceived that basic training, 
information or knowledge from courses related to other fields of care were relevant to solving problems in daily practice.

\subsection{Findings in study $B$}

The aim of the second paper (study B) was to explore what opportunities for learning were perceived by practitioners in rheumatology in their daily practice using a typology of workplace learning to characterize the findings.

The results show that the typology of workplace learning was largely satisfactory for categorizing our emergent findings. Some adjustments were made to the categories in the typology to fit our study data, and extensions of the typology were also proposed, as participation in research activities and teaching were found to be additional learning opportunities in both types of processes.

The data analysis using the typology also showed how participants (rheumatology specialists, registered nurses, physiotherapists, occupational therapists and social workers) perceived learning opportunities in both work processes with learning as a by-product and in recognized learning processes (Table 5).

Table 5. Opportunities for learning in clinical rheumatology practice, based on a typology of early career learning (Eraut, 2007).

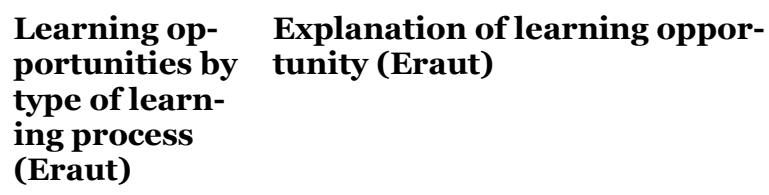

Learning opportunities by type of learning process (Eraut)

\section{Explanation of learning oppor-} tunity (Eraut)

\section{Recognized learning processes}

\begin{tabular}{lll}
\hline \multicolumn{2}{l}{ Recognized learning processes } & \\
\hline $\begin{array}{l}\text { Visits to other } \\
\text { sites }\end{array}$ & $\begin{array}{l}\text { Formal extensions to the observation } \\
\text { opportunities available through learn- } \\
\text { ers' normal work }\end{array}$ & $\begin{array}{l}\text { Study visit to other rheu- } \\
\text { matology clinics }\end{array}$ \\
\hline Conferences & Structured meetings with an agenda* & $\begin{array}{l}\text { In-house lectures for all } \\
\text { staff; pharmacological } \\
\text { company visits; regional, } \\
\text { national and international } \\
\text { rheumatology conferences }\end{array}$ \\
& & $\begin{array}{l}\text { Specialty course at uni- } \\
\text { versity; professional } \\
\text { course; course through } \\
\text { pharmaceutical company; }\end{array}$ \\
\hline Short courses & $\begin{array}{l}\text { Structured meetings with a curricu- } \\
\text { lum and in some cases a knowledge } \\
\text { assessment of the participant* }\end{array}$ & \\
\hline
\end{tabular}

Opportunities for learning in clinical rheumatology practice found in this study 
formal in-house exchange with other specialties

\begin{tabular}{lll}
\hline $\begin{array}{l}\text { Independent } \\
\text { study }\end{array}$ & $\begin{array}{l}\text { Training supported by knowledge re- } \\
\text { sources and/or agreed plans, such as } \\
\text { lists of competences, learning projects } \\
\text { or personal development plans }\end{array}$ & $\begin{array}{l}\text { Searching and reading re- } \\
\text { search articles, books, } \\
\text { popular journals, internet } \\
\text { resources }\end{array}$ \\
\hline $\begin{array}{l}\text { Proposed new } \\
\text { categories/ } \\
\text { learning oppor- } \\
\text { tunities by the } \\
\text { authors: }\end{array}$ & $\begin{array}{l}\text { Explanation of proposed new catego- } \\
\text { ries/learning opportunities by the au- }\end{array}$ & $\begin{array}{l}\text { In rheumatology prac- } \\
\text { tice: }\end{array}$ \\
& &
\end{tabular}

Assigned teach- Formally recognized professional or ing role inter-professional teaching responsibilities towards students and/or peers in or outside the clinical specialty*
Supervising students and receiving concomitant training; coordinating continued professional education in the clinic; formal consulting role

Using research results to inform practice
Research activi
ties (project manager)
(Co-)managing a research project, responsible for producing end results of study*

\section{Working processes with learning as a by-product}

\begin{tabular}{lll}
\hline Participation in & Team working towards a common & Informal professional \\
group processes & $\begin{array}{l}\text { outcome, and groups set up for a spe- } \\
\text { cial purpose such as discussing a cli- } \\
\text { ent, problem solving, reviewing some } \\
\text { practices, planning ahead or respond- }\end{array}$ & Patient conferences \\
& $\begin{array}{l}\text { ing to external changes } \\
\end{array}$
\end{tabular}

Consultation Consultations within or outside the working group or even outside the organization, used to coordinate activities or to get advice
Personal consulting with colleagues with specialized knowledge or more experience in the clinic or with colleagues in other specialty units

Learning from peers in the course of clinical practice

Reflection on one's own clinical experience
Tackling chal- lenging tasks and roles
Tackling challenging tasks and roles requires on-the-job learning and, if well supported and successful, leads to increased motivation and confi- dence

Working alongside others allows ple to observe and listen to others at work

\begin{tabular}{lll}
\hline $\begin{array}{l}\text { Trying things } \\
\text { out; consolidat- } \\
\text { ing, extending }\end{array}$ & $\begin{array}{l}\text { Trying things out is distinguished } \\
\text { from less purposeful behaviour by the } \\
\text { intention to learn from the experience }\end{array}$ & $\begin{array}{l}\text { Practicing professional } \\
\text { skills }\end{array}$ \\
\hline
\end{tabular}


and refining

skills

Working with clients
Entails learning (1) about the client,

(2) from any novel aspects of each client's problem or request and (3) from any new ideas that arise from the encounter. There can also be a strong emotional dimension

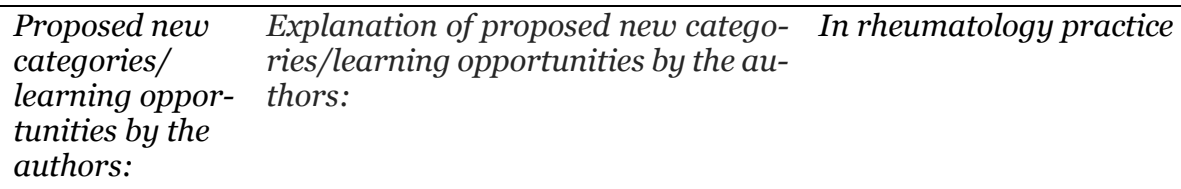

Unassigned Purposeful sharing of knowledge and teaching role skills with peers and patients to enhance quality of care, without mandate or curriculum*
Preparing an informal session with the professional group; sharing research literature with peers; patient education; unofficial consulting role

$\begin{array}{ll}\text { Research activi- } & \text { Being involved in a research project, } \\ \text { ties (assisting) } & \text { without being responsible for produc- } \\ \text { ing end results of study* }\end{array}$

Being informed by researchers about a research project, before and in the course of collection and registration of study data

\footnotetext{
*Explanation by authors.
}

In work processes with learning as a by-product, participants perceived professional meetings with their peers to be one of the most rewarding opportunities for learning. Participation in group processes included both profession-specific meetings and exchanges with colleagues from other professions, but organized exchanges with colleagues from other professions focused mostly on patients and their direct needs in the context of rounds and patient conferences. Participants most often sought professional advice within their own professional group.

Working with patients was mentioned by many as a significant learning activity, leading to a deeper personal understanding of the perceptions and consequences of disease and clarifying which treatments worked and which did not, but also as a way of building a relationship with the patient over time.

Working alongside others, trying things out and consolidating, extending and refining skills were engaged in by those with shorter work experience. 
Several experienced participants perceived that engaging in unassigned teaching in the workplace context provided opportunities for learning. Those involved in research activities also perceived this as a learning opportunity, as well as presenting network opportunities outside the clinic.

Recognized learning processes included shadowing, being supervised, being coached and being mentored. These learning opportunities were not mentioned by any of the participants.

Visits to other sites were not perceived as being planned to meet individual learning needs, but as a way to explore alternative work routines and organizational matters. Many participants perceived other recognized learning opportunities, such as in-house lectures, rheumatology conferences and professional and academic courses, as valuable learning opportunities, but reported that these opportunities were infrequent and did not occur regularly.

Assigned teaching was valued by some participants. Having trainees involved formal training and stimulated self-directed learning. Research projects gave some participants the opportunity to learn about the research subject and to consider applying the results from research to practice. Participants perceived that time for independent study was scarce in most units, however.

\subsection{Findings in study $C$}

The aims of the third study (study C) were to examine to what extent EBP was implemented in clinical rheumatology practice, and to determine which individual and organizational factors influenced research use.

The survey questionnaire collected data about socio-demographic factors, social-cognitive factors, EBP implementation climate, and EBP implementation leadership.

Socio-demographic data included age, profession, postgraduate education, experience in profession, experience in clinical rheumatology, experience of research activities and the number of professional peers in the work group. The social-cognitive factors included respondents' assessment of their personal ability to use research evidence, perceived value of research evidence for clinical practice, their intention to use research evidence, their 
estimation of their peers' use of research evidence and their estimation of respected colleagues' use of research evidence.

Responses to the five items concerning the social-cognitive factors influencing EBP implementation showed that research evidence for clinical practice and the ratings of the respondents concerning their intention to use research evidence in the future were high. Respondents' assessment of their personal ability to use research in practice was generally somewhat lower. Only half of the respondents estimated that a respected colleague often or always used research in practice, and $15 \%$ of the respondents believed that a respected colleague rarely used research. Less than a quarter of the respondents estimated that a high percentage (81-100\%) of their peers used research in practice.

The average score on the EBP Implementation Climate Scale was 32.6 (standard deviation [SD], 12.4; range, 3-62). Since the measure is new and use of the scale is limited, no conclusions can be drawn concerning the score. More than half of the respondents agreed to a great extent to the items "One of my workplace's main goals is to use evidence-based practices effectively", "People in my workplace think that the implementation of evidence-based practices is important" and "Using evidence-based practices is a top priority in my workplace".

The average score on the Implementation Leadership Scale was 21.8 (SD, 11.4; range, $0-48$ ). Since the measure is new and use of the scale is limited, no conclusions can be drawn concerning the score. Respondents assessed their leaders to be knowledgeable about and supportive of EBP, for the most part, but did not find them quite as proactive and perseverant in matters concerning EBP.

The average score for the outcome measure, the EBP Implementation Scale, varied, with a mean score of 12.1 (SD, 11.6; range, $0-61$ ). There is a scarcity of research using the scale, but the studies that are cited show some congruity with other research. The activities that were reported as being performed most often by the majority of the respondents once or more during the previous 8 weeks of practice were "sharing evidence from a research study with patients and the families," "informally discussing evidence from a research study," and "using evidence to change my practice". Some of the other EBP activities were performed seldom or not very often. 


\section{EBP IMPLEMENTATION}

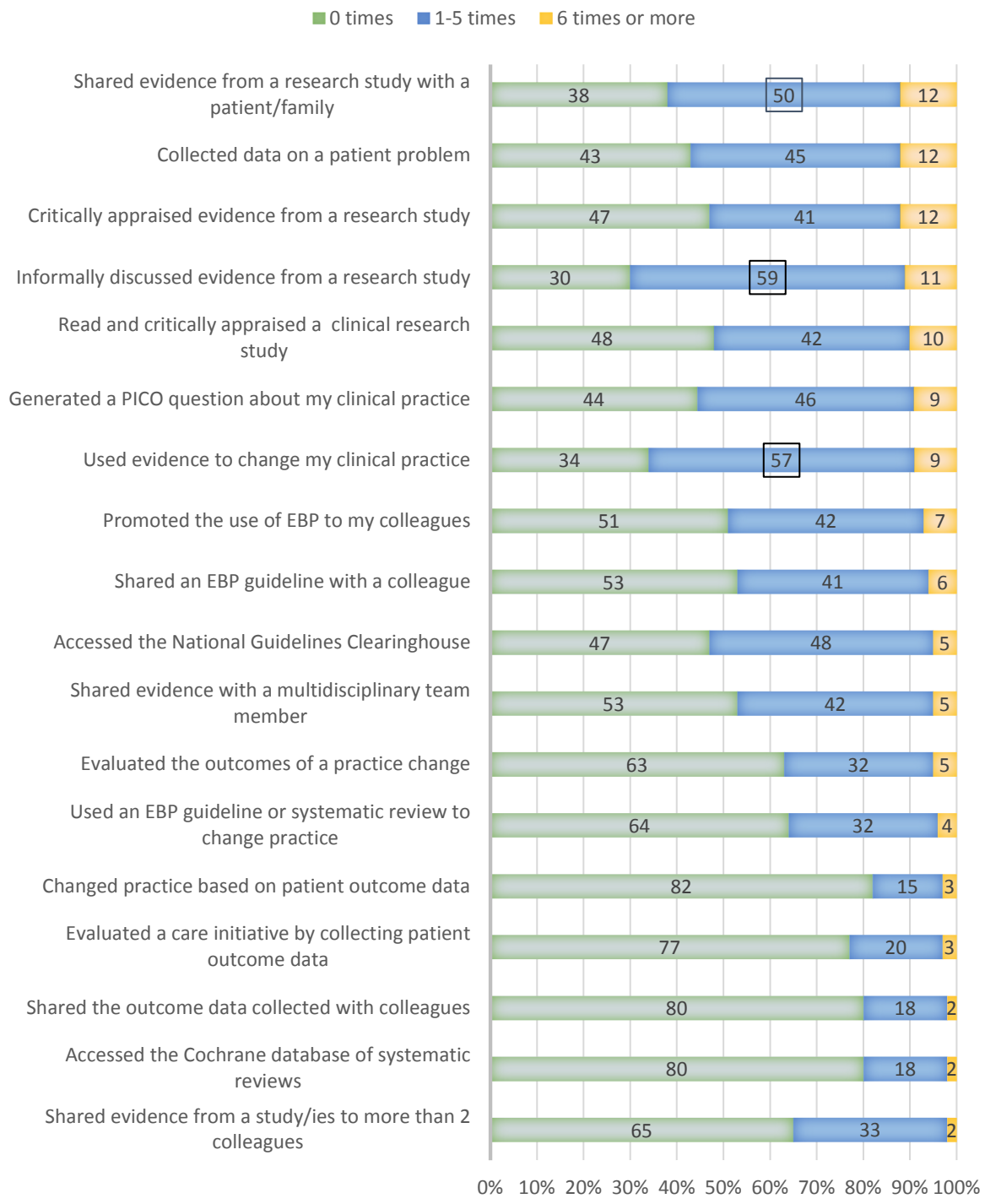

Figure 2. Responses to items on the EBP Implementation Scale shown as proportions (\%) of the total number of respondents per item. Responses indicate how many times in the past 8 weeks study participants performed the item: o times, $1-5$ times or 6 times or more.

A logistic regression analysis was carried out to determine which factors were associated with a higher score on the EBP Implementation Scale. The 
analysis showed three factors had a positive association with the implementation of EBP: a greater perception of personal ability to use research knowledge, more years of experience in clinical rheumatology, and more experience of research activities were associated with a higher score on the EBP Implementation Scale.

\subsection{Findings in study $D$}

The fourth and last study (study D) sought to analyse the learning processes involved in implementing EBP in healthcare. In this study, EBP-related challenges were described as related to not only the acquisition of EBP skills and adoption of evidence-based interventions but also to the abandonment of ingrained non-evidence-based practices.

Adaptive and developmental learning processes were found to be instrumental in implementing EBP. On the one hand, a clinician may develop a habitual practice of seeking out, critiquing and integrating research into everyday clinical practice and adopting new interventions best supported by empirical evidence. This behaviour will be smoother and more efficient through adaptive learning. On the other hand, the process of making habits explicit and reflecting on behaviour (developmental learning processes) will assist the clinician in learning to disrupt existing habits in order to apply more EBPs (Figure 3).

Mode of learning involved in implementing EBP

\begin{tabular}{|c|l|l|}
\cline { 2 - 3 } \multicolumn{1}{c|}{$\begin{array}{c}\text { EBP problem-sol- } \\
\text { ving process }\end{array}$} & $\begin{array}{l}\text { Adaptive learning } \\
\text { Acquiring EBP skills and using } \\
\text { them in regular practice }\end{array}$ & $\begin{array}{l}\text { Developmental learning } \\
\text { Avoiding over-reliance on clinical } \\
\text { practice habits to enable the appli- } \\
\text { cation of the EBP problem-solving } \\
\text { process in regular practice }\end{array}$ \\
\hline $\begin{array}{c}\text { Evidence-based in- } \\
\text { terventions }\end{array}$ & $\begin{array}{l}\text { Learning evidence-based inter- } \\
\text { ventions (programmes, meth- } \\
\text { ods, services, etc.) and providing } \\
\text { them to patients as part of regu- } \\
\text { lar practice }\end{array}$ & $\begin{array}{l}\text { Modifying or discarding habitual } \\
\text { attitudes, beliefs, knowledge and } \\
\text { behaviours that hinder learning } \\
\text { and effective use of new evidence- } \\
\text { based interventions in regular } \\
\text { practice }\end{array}$ \\
$\begin{array}{l}\text { De-implementation to abandon } \\
\text { current interventions that are not } \\
\text { sufficiently evidence-based }\end{array}$ \\
\hline
\end{tabular}

Figure 3. Learning challenges involved in implementing EBP. 


\subsection{Summary of findings}

The overall aim of the research project was to generate knowledge concerning the learning challenges associated with EBP in rheumatology.

The qualitative data showed that social workplace interactions were perceived as very significant and influenced learning in the clinic in several ways. The nurses in the first study perceived interactions with peers, physicians and patients as their preferred sources of knowledge. Nurses also perceived their previous knowledge and experience as a knowledge source. Members of all professional groups expressed that professional meetings with their peers, working with patients and working alongside others were rewarding learning opportunities.

The studies showed that time for reflection and updating knowledge was perceived to be short in rheumatology practice. This was perceived by participants as a barrier for both learning in general and for the use of research in practice.

Access to professional networks and formal education was perceived to be limited by the rheumatology nurses. Nurses and other professional groups perceived recognized a lack of learning opportunities, such as continuing professional education and regular participation in rheumatology-specific courses and conferences, and some of the learning opportunities in the learning typology were not mentioned at all by participants. Learning occurred mostly through in-house exchanges.

A large variation in levels of implementation of EBP was found, and although a low general standard is indicated (even if a gold standard does not exist), there was also a great general interest in EBP. Better perceived personal ability to use research knowledge, more years of experience in clinical rheumatology, and experience of research activities were the factors found to influence the implementation of EBP.

Study D focused on learning processes that are instrumental to the implementation of EBP. The theoretical analysis using learning theory showed that the challenges of the implementation of EBP involve dual learning processes, which lead to smoother and more automatic EBP behaviour on the one hand, but also to reflective learning processes that may disrupt inappropriate habitual behaviour on the other hand. 
When taken together, the findings from the qualitative and quantitative data present a complex picture that shows how social and contextual conditions and individual characteristics and learning processes may interact to shape learning and EBP implementation behaviours in rheumatology practice. 


\section{DISCUSSION}

The first three sections discuss connective themes between the studies concerning social, contextual and individual aspects of learning and EBP, using a workplace learning theory (Eraut 2007) and the COM-B model (Michie et al. 2005) to structure the discussion.

In the fourth section, the methods that were used in the thesis are discussed, and the chapter concludes with some reflections on future studies.

\subsection{Social aspects of learning and evidence-based practice}

Most modern learning theorists underscore the importance of social processes for learning, and this is reflected in the findings in the thesis. The qualitative data showed that social processes in the workplace seemed to be central for learning. In study A, discussions with peer nurses and physicians were a preferred source of knowledge. In study B, study participants belonging to different professional groups perceived informal discussions at meetings with their professional peers in the workplace to be important learning opportunities. Study C, which aimed to examine factors that influenced the use of research knowledge in practice, also highlighted that activities with a social character were preferred by many respondents over individually executed activities, such as independent study.

Nurses as a professional group are not alone in their preference for peers as sources of knowledge. Other health professionals also prefer experts as sources of information (Dawes and Smpson 2003; Fitzgerald and Dopson 2005a; McGettigan et al. 2001). Single professional-based groups and associated networks can provide a powerful community of practice, a workrelated community created through sustained collective pursuit of a shared enterprise (Wenger 1998).

There were signs of tension between professional groups in the studies. In study A, the development of the nurses' role was perceived by the nurses as a subject of conflict in some contexts and not even negotiable in others. In study B, some opportunities for learning were perceived as being off limits to individual health professionals. Research on professional socialization 
shows that a strong identification with a professional group with its own behaviours, values and attitudes, often leads to social and cognitive boundaries between different professional groups that can form barriers for the diffusion of knowledge between groups (Ferlie 2005). Nurses perceived that physicians teaching nurses was the rule not the other way around. The unchanged power hierarchy of doctors, nurses and other healthprofessionals influences how roles change and how knowledge is diffused, and has been found to be a barrier for the diffusion of knowledge in inter-professional practice contexts (Fitzgerald and Dopson 2005b).

\subsection{Contextual aspects of learning and evidence- based practice}

The conditions for workplace learning have been a focus for many learning theories (Billett 2000; Eraut 2007; Illeris 2011). In the two-triangle model, a triangular relationship between challenge, support and confidence is proposed (Eraut 2007). This model may serve to analyse the findings in the thesis in the following way.

Ideally, employees would find themselves allocated to work tasks that they valued and that had the right level of challenge (Eraut 2007). The relatively low frequency of performing most EBP-related activities found in study C points to the possibility that EBP is experienced as a challenge that could be better adjusted to the individual worker in rheumatology. In addition, work could be structured to give employees the opportunity to apply EBP in ways tailored to their own values and interests, but also to their ability. Although the demand for best practice would apply to all employees, not all employees would be using the EBP "doing" mode. Some employees will favour the EBP "user" mode, in which the critical appraisal process is restricted to using rigorously pre-appraised sources. Many will also opt to trust and directly follow the recommendations of respected, evidencebased opinion leaders (EBP "replicating" mode), which was discussed in study A as a way to integrate more nursing research into the clinic. All three modes stay true to the original EBP in that they allow the integration of best practice with professional expertise and the patient's unique preferences and circumstances (Straus 2007).

Ideally also, leaders and employees work together to support encounters at work. According to Eraut (2007), positive relationships engender feedback and support to employees. Several participants in studies A and B expressed that they perceived that time for reflection and updating knowledge was short during work hours. In study B, recognized learning 
opportunities, e.g. independent study and other educational activities, were not a regular occurrence in the workplace and the participants perceived unorganized meetings as their main source of knowledge and opportunity for learning. The need for feedback and support for learning and EBP in rheumatology may therefore involve finding ways to organize clinical work to explicitly include encounters for the exchange of research-based and experiential knowledge. A practitioner with basic EBP skills may, given the necessary resources, be sufficiently proficient at formulating answerable questions and executing the steps in a critical appraisal process, but a colleague with less skills and knowledge of EBP will need support at different levels. This may involve asking other people in the workplace and locating resources for EBP.

Empirical studies by Eraut (2007) show different aspects of the professional confidence that employees associated with work experience (related to the capacity to execute a particular task or successfully perform a role), and with feeling confident about the support and trust of their working colleagues. Applying this to EBP, professional confidence should ideally also include feeling more confident about using relevant research knowledge in the field of practice. Leaders need expect workers' commitment to EBP, and to adequately coach workers, they must supply timely and task-specific feedback (Eraut 2007).

In the contexts in the studies, leadership and climate did not stand out as influential for learning or as opportunities to implement EBP, however. In studies A and B, managers were scarcely mentioned and leadership was mostly invisible. Learning opportunities that are dependent on leadership engagement; mentoring strategies and coaching did not feature.

In learning literature, the concept of a learning climate is referred to in terms of explicit structural and personal attention to adult learning (Boud and Middleton 2003; Eraut 2007; Illeris 2011). Leadership is viewed as important for the creation of a learning climate by many theories, as workers are influenced by their leaders' expectations of their work performance (Ehrhart et al. 2014; Schneider et al. 2005).

Clinical leaders in rheumatology (similar to other fields of health care) are often recruited from a professional group, often the medical profession. Fitzgerald and Dopson (2005a) note that this is motivated by the link between professional credibility and professional knowledge. Often, managers work part-time in the managerial role and as doctors have a high social status in their professional role; this role may take precedence over their 
leadership role, the manager role being deemed as low status and easy to learn.

Although managers have a very important role in shaping both the climate and conditions for learning, other issues may interfere with this part of the clinical manager's role. Beckett (2000) characterizes the work of a manager as brevity, fragmentation and communication, in short as "hot action". This may explain the invisibility of leadership in the studies.

\subsection{Individual aspects of learning and evidence- based practice}

In the following, the COM-B-model introduced in the background section is used to analyse the findings. The model has three components: capacity, opportunity and motivation.

As was shown in study C, respondents' perception of their personal ability to use research for practice and respondents personal experience of research-related activities influenced the implementation of EBP. These findings highlight the importance of individual capacity for EBP. The individual experience of having participated in research influenced respondents' selfreported implementation of EBP, independently of other factors. A longer experience in the specialty was also a factor related to a higher degree of EBP implementation. Our analysis (in study D) of the learning processes in relation to the implementation of EBP gives a new perspective on these findings. Professionals who have been working in rheumatology for a long time may not be as involved in honing their clinical skills, because expertise renders their actions smooth and efficient. This may free their mental energy to engage in developmental learning processes.

Concerning opportunities for learning, the qualitative studies showed that social processes, predominantly with professional peers in the clinic, were appreciated as knowledge sources and learning opportunities, but that the opportunities for sharing knowledge and for reflection in practice were dependent on informal initiatives rather than being strategically organized. Learning theorists stress the importance of reflection as a way to codify tacit knowledge, and to integrate codified and experiential knowledge (Boud and Middleton 2003; Ellström 2006; Nilsen et al. 2012; Nutley et al. 2007). Although informal learning is often not acknowledged as learning in organizations, Boud and Middleton (2003) argue that there is a value to rendering learning visible so that it can be consciously used to enhance 
work and the quality of work life. In relation to EBP, Straus and Haynes (2009) call for a better infrastructure for the management of evidencebased knowledge.

Leadership did not stand out as a factor that influenced the implementation of EBP in the studies. This was a surprise, because factors at the level of organizational context have been proposed as central in many implementation frameworks (Greenhalgh et al. 2005; Nutley et al. 2007; RycroftMalone and Bucknall 2010; Stetler et al. 2011). Cummings et al. (2007) found that culture, which was defined as leadership combined with evaluation, increased research utilization. In a study that aimed to determine the factors that predict research utilization among nurses, however, multilevel analysis showed that variation in research use was mainly explained by factors at the individual level, whereas specialty and organizational level factors contributed relatively little (Estabrooks et al. 2007).

The findings show that opportunities for learning outside the clinic were perceived as lacking, and that participation in courses and conferences was irregular. Participating in formal education outside the workplace and extending professional networks may be effective in enhancing learning and EBP. In a review, Cunningham et al. (2011) showed that effective professional networks contributed to the quality of care and patient safety through efficient transmission of information and social and professional interaction within and across networks.

Some of the participants in studies A and B were driven by a personal inner motivation towards personal enlightenment and sharing of knowledge with others. Some participants engaged in independent study despite the scarcity of time in the clinic; some engaged in teaching roles on their own initiative. They showed through their own initiatives that critical reflection is possible in a culture of busyness, and that their personal agency may inspire others to change their practice as well. Others were not interested and found reading and research boring.

In analysing resistance to learning, Illeris (2011) notes that learning incentives for individual learning are a factor that cannot be overlooked. There are both unconscious and conscious motivations for not wanting to engage in learning processes. Workplaces furnish activities that provide learners with combinations of experiences that assist them to extend and reinforce their knowledge, but learners need to actively engage with these opportunities for learning to occur (Billett 2000; 2008). 
With regard to the wider implications of the findings, there is no gold standard for the implementation of EBP; the results from study $\mathrm{C}$ are difficult to evaluate. Other studies have reported similar scores for the outcome instrument, predominantly in nursing populations (Mariano et al. 2009; Stokke et al. 2014; Yost et al. 2014). and as the scores are low in all studies, the results do not show that implementation of EBP in rheumatology should be a reason for special concern. As issues concerning measurement methods and conceptual issues are solved or overcome in the future, and the evidence base increases, the results may be seen in a clearer light.

\subsection{Future studies}

The results with regard to the social, contextual and individual aspects of learning and EBP in clinical rheumatology lead to some considerations concerning future studies.

As the users of research-based knowledge, intrinsically motivated individuals may become local opinion leaders and influence peers (Grimshaw et al. 2006). Because these individuals are often open to innovation, they may be influential in change processes in their organization but only if they have status and authority in the organization: in most cases, an individual's ability to change the larger group is limited without support from leaders, resources, strategies and structures (Rogers 2003). The use of respected opinion leaders as clinical EBP mentors has been shown to be effective as an implementation strategy in other contexts (Yost et al. 2015). Future studies may be able to contribute more on the efficacy of using experienced professionals with EBP skills as mentors in clinical rheumatology.

The implementation of EBP at the clinical level is highly dependent on how aware leaders and individuals at higher levels in health care organizations are of the need to support learning and EBP-related infrastructures (Greenhalgh et al. 2005). Skilled actions by powerful senior leadership can help make a difference in developing local contexts, as demonstrated by Fitzgerald et al. (2005). From this perspective, and referring to the COM-B model described earlier (see section 2.3.4), research on the capacity, opportunity and motivation of clinical leaders and leaders at higher levels of the organization would be an interesting research topic.

Another potentially interesting avenue of study would be research on the educational strategies for effectively supporting professionals and their leaders in rheumatology (and other health care fields) in implementing EBP in clinical practice. Currently, EBP is professed to be a top political 
priority at both national and regional levels, and societal discussions on the need for continuing professional education in health care are gaining momentum in Sweden. If this interest is sustained, institutes of higher education will need to cater more for the needs of professional education later in professional life, including educational support for (different levels of) EBP (Tilson, 2011).

\subsection{Methodological considerations}

The methodological aspects of the thesis are discussed at a more general level in this section. The reader is directed to the studies at the end of the thesis for details of the methods in each study. The use of different methods in the studies was connected to the research questions addressed in the different studies.

In studies $\mathrm{A}$ and $\mathrm{B}$, the aims of the studies were explorative, because not much was previously known about the knowledge sources of nurses in rheumatology or learning opportunities in clinical practice within the specialty. The focus was on the perceptions that were held by "professionals on the ground". This motivated the use of a qualitative method of enquiry.

In study A, conventional QCA was performed. The small group allowed a focused insight into the perceptions of the participants pertaining to knowledge sources for nursing practice. In study B, participants of different professional affiliations gave their opinions on opportunities for learning in the clinic. In this study, the categories resulting from a conventional QCA were structured using a typology.

The interviews resulted in an account of the perceptions of professionals in rheumatology, based on their own words in the interviews. This provides an interesting insight into the research issues and an understanding that may not have been reached by studying the issue by other methods.

The quality of research in general is warranted by accuracy in the use of scientific methods, transparency concerning the procedures followed in the course of the research and ethically sound judgments during the research process. The quality of qualitative research can be assessed through four quality criteria that together give an indication of the trustworthiness of the results. These criteria include the transferability, dependability, confirmability and credibility of the research (Guba 1981). 
The quality concept of transferability is related to the applicability of the findings to other settings. If sufficient and relevant details are supplied in the study, it is possible for the readers of the study to determine if the study is transferable to their particular setting. In both studies A and B, the characteristics of the different settings, the age, sex and professional background of the participants showed a breadth of experiences and perceptions in different contexts. As the data derive from an information-rich sample, a thoughtful and discerning extrapolation of the results to other contexts may be possible (Patton 2002).

The dependability aspect of quality concerns the totality of the research process. Do the research findings represent a credible analysis of the data? Was the research carried out according to the rules of good practice? The studies in this thesis were discussed in several seminars with the participation of experienced researchers from different disciplines, and several researchers with different background were actively involved with the data analyses.

Confirmability in qualitative research concerns the issue of objectivity, one of the most important and challenging issues pertaining to research in general, and to qualitative research in particular. Having previous experience of rheumatology practice naturally led to preconceptions on the part of the interviewer with regard to organizational characteristics and professional roles. Both the interviewer's personal reflections and discussions in the research group have countered some of the influences that these preconceptions had on the research process and its results. The interview guide was designed in collaboration with other members of the research group, and the analyses were carried out according to prescribed methodological procedures. The interviewer consciously considered personal values and preconceptions before and after every interview. Objectivity was further strengthened by the fact that other members of the research group, who had no experience of clinical roles or involvement in rheumatology practice, participated in the data analysis.

Credibility is defined as the congruency between data interpretations and the truth as perceived by participants. The research project did not allow for credibility-enhancing measures. This may have compromised the general trustworthiness.

In study C, the research question was: To what extent is EBP implemented in clinical rheumatology practice and which individual and organizational factors affect research use? A quantitative approach was used to study the 
aim, and validity, reliability and generalizability are the issues that must be examined to assess the quality of the study.

Recruitment for study $\mathrm{C}$ led to a certain selection-bias, as professionals interested in the use of research were more likely to respond to the questionnaire. Also, self-report measures have a documented risk of social desirability bias, which may have inflated the outcome score. Following this logic, EBP-implementation scores in the general population may be inferred to be lower.

The overall response rate (32\%) limits generalizability of results. An analysis of non-respondents indicated that there were no statistical differences between responders and non-responders concerning age, gender and continuing education, but other differences may limit the generalizability of the results to the larger population. For example, response rates varied among professional groups, from $17 \%$ among the physicians to $51 \%$ among the occupational therapists.

In screening the implementation literature for instruments in general, a review by Chaudoir et al. (2013) was helpful in finding instruments that had previously been used in the literature on implementation and research use. The review categorizes instruments into the five determinants that are now accepted by most implementation researchers as central in implementation literature: the innovation (implementation object), the provider (user), the organization (inner context), the patient and the structural factors around the implementation of the health innovation (outer context). The taxonomy may be used to describe the limitations of the scope of the questionnaire in study C. Even though characteristics of the larger context surrounding the rheumatology units and patient-related measures (measuring how patients influence the use of research-based knowledge in making evidence-based decisions) can be surmised to influence the outcome, these issues were not included in the study.

In designing the questionnaire, valid and reliable measures were used, even though we were limited in our choice of instruments in that the instrumentation in the field is underdeveloped (Lewis 2015). As has been noted in several reviews on measures of research utilization, there is a lack of conceptual clarity concerning EBP that has not been resolved, which also translates into a lack of robust instruments to measure it (Estabrooks et al. 2011; Squires et al. 2011b). The instrument that was used in the study was a reliable and valid outcome measure that has been tested empirically for measuring EBP-implementing behaviours in health care (Melnyk et al. 
2008), and the instrument includes a range of behaviours that coincide to a large degree with the indicators that were identified in the review (Estabrooks et al. 2011).

The instruments for measuring leadership and climate for EBP were new and relatively untested. Notwithstanding the relative incompleteness of the quality evaluation of the instrumentation, the questionnaire may be judged to have benefited from the use of theory in its design. The questionnaire items on the individual factors that influence the use of research in practice were based on socio-cognitive theory, and the instruments used to determine the contextual factors were explicitly based on organizational theory.

The construction of a questionnaire has many methodological aspects. The juxtaposition of the different instruments in relation to each other may have influenced our results. Also, although the translations of the instruments had excellent internal validity in the context of this study, other tests (e.g. of reliability and external validity) were not performed; therefore, caution is recommended with regard to their use in other contexts.

Before the start of the data collection, a small pilot study was conducted with a sample of 12 professionals working in the specialty. The participants in the pilot study were asked to complete the instrument and comment on the clarity of the items and suggest improvements. After several changes in phrasing and lay out, the instruments and items were judged to be comprehensible and ready to use. By conducting a pilot test, the questionnaire may be said to be validated to some extent.

In the process of writing study $\mathrm{D}$, discussions among the authors concerned aspects of everyday clinical practice, the role of habit in clinical practice, and the learning processes that make an enactment of the ideals of EBP possible. These processes concern the implementation of new knowledge into practice but also the de-implementation of methods and practices that have been demonstrated to be out of date and non-functional. This topic is receiving more and more attention in implementation research; the implementation of new methods is, or should be, closely adjunct to the discontinuation of non-evidence-based health practices (Nilsen et al. 2012). Having different backgrounds, the authors bought different perspectives to bear on the issue of implementation and de-implementation as a behaviour. 
Using theoretical discussions to clarify our thoughts about our actions is a way to make explicit some of the intuitive knowledge we have about why we act as we do in practice, and although the article gives no definitive solution to the problems of implementation of EBP, it will hopefully contribute to future discussions about learning and EBP behaviour in the clinic. 


\section{CONCLUSIONS}

In this thesis, learning and the implementation of EBP in rheumatology has been shown to be a complex issue. Social, contextual and individual learning aspects were found to be involved in the learning processes, the use of knowledge sources and learning opportunities, as well as in the EBP-behaviours that are enacted in clinical rheumatology.

Social aspects of learning were illustrated by perceptions of interactions in the workplace as preferred knowledge sources and opportunities for learning, and through the EBP activities that were engaged in most frequently.

Contextual aspects concerned the organizational structures that provide levels of work challenges, feedback and support, and confidence in the workplace, and participation in professional rheumatology networks and continuing education outside the clinic.

The individual learning aspects were the adaptive and developmental learning processes involved in the enactment of EBP behaviour, and factors concerning the capacity, opportunity and motivation for EBP-related behaviour.

Discussions on what EBP is and how it can be implemented are ongoing, but the rationale for striving to use research knowledge in rheumatology as in other fields of health care seems convincing, because it is about achieving the best possible health care for patients. Although professional judgment remains a key skill, and patients' preferences should be taken into account in any situation, there is tremendous potential for benefit to patients by promoting the widespread use of evidence for effective practices (Grol et al. 2005; Nutley et al. 2007).

In this thesis, using learning and behaviour theories, some aspects of implementing EBP in rheumatology have been explored that may contribute to a better understanding of EBP implementation. And although the challenges of implementing EBP may seem daunting, the thesis hopes to have contributed to a platform for discussion on how to meet these challenges. 


\section{REFERENCES}

Aarons, G., et al. (2014), The implementation leadership scale (ILS): development of a brief measure of unit level implementation leadership, Implementation Science, 9 (1), 45.

Ahlmén, M., et al. (2005), Rheumatology outcomes: the patient's perspective. A multicentre focus group interview study of Swedish rheumatoid arthritis patients, Rheumatology, 44 (1), 105-10.

Ahlstrand, I., et al. (2015), Pain and activity limitations in women and men with contemporary treated early RA compared to 10 years ago: the Swedish TIRA project. Scandinavian Journal of Rheumatology, 44 (4), 259-64.

Argyris, C., Schön, D.A. (1974), Theory in practice: increasing professional effectiveness (San Francisco, CA: Jossey-Bass).

Bandura, A. (1997), Self-efficacy: the exercise of control (New York: Freeman).

Bang, H. (2009), Organisationskultur (Malmö: Studentlitteratur).

Bartels, E.M. (2009), How to keep up with medical literature, Best Practice \& Research: Clinical Rheumatology, 23 (2), 281-90.

Beckett, D. (2000), Past the guru and up the garden path. The new organic management learning, in D. Boud, J. Garrick (eds.), Understanding learning at work (London: Routledge).

Billett, S. (2000), Guided learning at work, in D. Boud, Garrick, J. (eds.), Understanding learning at work (London: Routledge), pp. 151-64.

Billett, S. (2008), Learning throughout working life: a relational interdependence between personal and social agency, British Journal of Educational Studies, 56 (1), 39-58.

Björk, M., et al. (2015), Validation and internal consistency of the Swedish version of the Valued Life Activities scale, Clinical Rehabilitation, doi:10.1177/0269215515616665.

Bohlin, I., Sager, M. (2011), Evidensens många ansikten (Lund: Arkiv, 2011 (Lettland)).

Boshoff, N. (2014), Types of knowledge in science-based practices, Journal of Science Communication, 13 (03).

Boud, D., Middleton, H. (2003), Learning from others at work: communities of practice and informal learning, Journal of Workplace Learning, 15 (5), 194-202.

Brownson, R.C., Colditz, G.A., Proctor, E.K. (2012), Dissemination and implementation research in health (New York: Oxford University Press).

Cane, J., O'Connor, D., Michie, S. (2012), Validation of the theoretical domains framework for use in behaviour change and implementation research, Implementation Science, 7, 37. 
Chaudoir, S.R, Dugan, A.G., Barr, C.H.I. (2013), Measuring factors affecting implementation of health innovations: a systematic review of structural, organizational, provider, patient, and innovation level measures, Implementation Science, 8, 22.

Chen, Y.F., et al. (2006), A systematic review of the effectiveness of adalimumab, etanercept and infliximab for the treatment of rheumatoid arthritis in adults and an economic evaluation of their cost-effectiveness, Health Technology Assessment, 10, 1-229.

Conlon, T.J. (2004), A review of informal learning literature, theory and implications for practice in developing global professional competence, Journal of European Industrial Training, 28(2-4), 283-95.

Creswell, J.W. (2007), Qualitative inquiry and research design: choosing among five traditions (Thousand Oaks, CA: Sage).

Cummings, G.G., et al. (2007), Influence of organizational characteristics and context on research utilization, Nursing Research, 56(4), S2439.

Cunningham, F.C., et al. (2011), Health professional networks as a vector for improving healthcare quality and safety: a systematic review, BMJ Quality \& Safety, doi:10.1136/bmjqs-2011-000187.

Damschroder, L.J., et al. (2009), Fostering implementation of health services research findings into practice: a consolidated framework for advancing implementation science, Implementation Science, 3, 1.

Dawes, M., Smpson, U. (2003), Knowledge management in clinical practice: a systematic review of information seeking behaviour in physicians', International Journal of Medical Informatics, 71, 9-15.

de Wit, M.P.T., et al. (2011), European League Against Rheumatism recommendations for the inclusion of patient representatives in scientific projects, Annals of the Rheumatic Diseases, 70(5), 722-26.

Deighton, C., et al. (2009), Management of rheumatoid arthritis: summary of NICE guidance, $B M J$, 338:b702.

Dewey, J. (1938), Experience and education (New York: Collier).

Dopson, S., et al. (2005), Evidence-based health care and the implementation gap, in S. Dopson, L. Fitzgerald (eds.), Knowledge to action? Evidence-based health care in context (Oxford: Oxford University Press ), pp. 28-47.

Dougados, M, et al. (2004), EULAR standardised operating procedures for the elaboration, evaluation, dissemination, and implementation of recommendations endorsed by the EULAR standing committees, Annals of the Rheumatic Diseases, 63(9), 1172-76.

Dreyfus, S.E., Dreyfus, H.L. (1980), A five-stage model of the mental activities involved in directed skill acquisition (Washington, DC: Storming Media).

Eccles, M.P., Mittman, B.S. (2006), Welcome to Implementation Science, Implementation Science, $1,1$. 
Ehrhart, M.G., Aarons, G.A., Farahnak, L. (2014), Assessing the organizational context for EBP implementation: the development and validity testing of the Implementation Climate Scale (ICS), Implementation Science, 9, 159.

Ellström, P.-E. (1992), Kompetens, utbildning och lärande $i$ arbetslivet: problem, begrepp och teoretiska perspektiv (Stockholm: Publica).

Ellström, P.-E. (2001), Integrating learning and work: conceptual issues and critical conditions, Human Resource Development Quarterly, $12,421-35$.

Ellström, P.-E. (2006), The meaning and role of reflection in informal learning at work, in D. Boud, P. Cressey, P. Docherty (eds.), Productive reflection. An anthology on reflection and learning at work (London: Routledge).

Ellström, P.-E. (2010), Practice-based innovation: a learning perspective, Journal of Workplace Learning, 22 (1), 27-40.

Ellström, P.-E., Illeris, K. (2004), Workplace learning - Scandinavian perspectives, Journal of Workplace Learning, 8, 16.

Elo, S., Kyngäs, H. (2008), The qualitative content analysis process, Journal of Advanced Nursing, 62(1), 107-15.

Eraut, M. (2000), Non-formal learning and tacit knowledge in professional work, British Journal of Educational Psychology, 70, 113-36.

Eraut, M. (2007), Learning from other people in the workplace, Oxford Review of Education, 33(4), 403-22.

Estabrooks, C.A., et al. (2011), Towards better measures of research utilization: a collaborative study in Canada and Sweden, Journal of Advanced Nursing, 67(8), 1705-18.

Estabrooks, C.A., Winther. C., Derksen, L. (2004), Mapping the field. A bibliometric analysis of the research utilization literature in nursing, Nursing Research, 53, 293-303.

Estabrooks, C.A., et al. (2007), Predicting research use in nursing organizations: a multilevel analysis, Nursing Research, 56(4 Suppl), S7-23.

Evidence Based Medicine Working Group (1992), Evidence-based medicine: a new approach to teaching the practice of medicine, JAMA, 268, 2420-25.

Fenwick, T. (2008), Workplace learning. Emerging trends and new perspectives, New Direction for Adult and Continuing Education (Special issue. Third Update on Adult and Continuing Education). (119), 17-26.

Ferlie, E. (2005), Conclusion: from evidence to actionable knowledge?, in S. Dopson, L. Fitzgerald (eds.), Knowledge to action? Evidencebased care in context (Oxford: Oxford University Press).

Fitzgerald, L., Dopson, L. (2005a), Professional boundaries and the diffusion of innovation, Knowledge to action? Evidence-based health care in context (Oxford: Oxford University Press).

Fitzgerald, L., Dopson, S. (2005b), Professional boundaries and the diffusion of innovation, in S. Dopson, L. Fitzgerald (eds.), Knowledge to 
action? Evidence-based health care in context (Oxford: Oxford University Press).

Fitzgerald, L., et al. (2005), Knowledge in action, in S. Dopson, L. Fitzgerald (eds.), Knowledge to action? Evidence-based health care in context (New York: Oxford University Press).

Forsman, H., et al. (2010), Use of research by nurses during their first two years after graduating, Journal of Advanced Nursing, 66(4), 87890.

Gerrish, K., Clayton, J. (2004), Promoting evidence-based practice: an organizational approach, Journal of Nursing Management, 12(2), 11423.

Gerrish, K., et al. (2012), Factors influencing advanced practice nurses' ability to promote evidence-based practice among frontline nurses, Worldviews on Evidence-Based Nursing, 9(1), 30-39.

Gray, M. (2009), Evidence-based healthcare and public health (Edinburgh: Churchill Livingstone).

Greenhalgh, T., et al. (2005), Diffusion of innovations in health service organisations. A systematic literature review (Oxford: Blackwell Publishing).

Grimshaw, J.M., et al. (2006), Is the involvement of opinion leaders in the implementation of research findings a feasible strategy?, Implementation Science, 1(1), 1-12.

Grol, R., Wensing, M., Eccles, M. (2005), Improving patient care: the implementation of change in clinical practice (Edinburgh: Elsevier).

Guba, E. (1981), Criteria for assessing the trustworthiness of naturalistic enquiries, Educational Technology Research \& Development, 29, 75-91.

Hagel, S., et al. (2010), Team-based rehabilitation improves long-term aerobic capacity and health-related quality of life in patients with chronic inflammatory arthritis, Disability \& Rehabilitation, 32(20), 1686-96.

Hansen, H.F. (2014), Organisation of evidence-based knowledge production: evidence hierarchies and evidence typologies, Scandinavian Journal of Public Health, 42(13 suppl), 11-17.

Hodkinson, P., Rainbird, H. (2006), Improving workplace learning. An integrated approach, in K. Evans, et al. (eds.), Improving workplace learning (London, New York: Routledge).

Hsieh, H.F., Shannon, S.E. (2005), Three approaches to qualitative content analysis, Qualitative Health Research, 15(9), 1277-88.

Illeris, K. (2009), Contemporary theories of learning : learning theorists in their own words (New York: Routledge).

Illeris, K. (2011), The fundamentals of workplace learning : understanding how people learn in working life (1st edn.) (New York: Routledge).

Järvholm, B., Bohlin, I. (2014), Evidence-based evaluation of information: the centrality and limitations of systematic reviews, Scandinavian Journal of Public Health, 42(13 suppl), 3-10. 
Kajermo, K.N., et al. (2010), The BARRIERS scale--the barriers to research utilization scale: a systematic review, Implementation Science, 5, 32.

Kalkan, A., et al. (2015), Physician preferences and variations in prescription of biologic drugs for rheumatoid arthritis: a register-based study of 4,010 patients in Sweden, Arthritis Care and Research, 67 (12).

Karasek, R.A., Theorell, T. (1990), Healthy work: stress, productivity, and the reconstruction of working life (New York: Basic Books).

Klareskog, L., Saxne, T., Enman, Y. (2005), Reumatologi (Lund: Studentlitteratur).

Kolb, D. (1984), Experiential learning. Experience as the source of learning and development (New Jersey: Prentice Hall).

Krippendorff, K. (2004), Content analysis : an introduction to its methodology (Thousand Oaks, CA: Sage).

Kvernbekk, T. (2011), The concept of evidence in evidence-based practice, Educational Theory, 61(5), 515-32.

Larsson, I. (2013), Person-centred care in rheumatology nursing in patients undergoing biological therapy: an explorative and interventional study, PhD thesis, Health and Caring Sciences, Jönköping University.

Légaré, F., et al. (2015), The majority of accredited continuing professional development activities do not target clinical behavior change, Academic Medicine, 90(2), 197-202.

Lewis, C.C., et al. (2015), The Society for Implementation Research Collaboration Instrument review project: a methodology to promote rigorous evaluation, Implementation Science, 10(2), 1-18.

Mariano, K.D., et al. (2009), Building evidence-based practice with staff nurses through mentoring, Journal of Neonatal Nursing, 15, 81-87.

Marsick, V.J., Watkins, K.E. (1990), Informal and incidental learning in the workplace (London: Routledge).

McKee, A., Eraut, M. (eds.) (2012), Learning trajectories, innovation and identity for professional development. Innovation and change in professional education, vol. 7 (Dordrecht: Springer).

McGettigan, P., et al. (2001), Prescribers prefer people: the sources of information used by doctors for prescribing suggest that the medium is more important than the message, British Journal of Clinical Pharmacology 51, 184-89.

Melnyk, B.M., Fineout-Overholt, E., Mays, M.Z. (2008), The evidence based practice beliefs and implementation scales: psychometric properties of two new instruments, Worldviews on Evidence Based Nursing, 5(4), 208-16.

Merriam, S.B., Caffarella, R.S., Baumgartner, L.M. (2007), Learning in adulthood: a comprehensive guide (San Francisco, CA: JosseyBass).

Michie, S., et al. (2005), Making psychological theory useful for implementing evidence based practice: a consensus approach, Quality \& Safety in Health Care, 14, 26-33. 
Michie, S., et al. (2008), From theory to intervention: mapping theoretically derived behavioural determinants to behaviour change techniques, Applied Psychology, 57(4), 660-80.

Midgley, N. (2009), Disseminators vs revisionists: attitudes to the "implementation gap" in evidence-based practice, Journal of Children's Services, 4, 28-38.

Mullen, E.J. (2014), Evidence-based knowledge in the context of social practice, Scandinavian Journal of Public Health, 42(Suppl 13), 5973 .

Nam, J.L., et al. (2010), Current evidence for the management of rheumatoid arthritis with biological disease-modifying antirheumatic drugs: a systematic literature review informing the EULAR recommendations for the management of RA, Annals of the Rheumatic Diseases, 69(6), 976-86.

Nilsen, P. (2015), Making sense of implementation theories, models and frameworks, Implementation Science, 10, 53.

Nilsen, P., Nordström, G., Ellström, P.-E. (2011), Integrating researchbased and practice-based knowledge through workplace reflection, Journal of Workplace Learning, 24(6), 403-15.

Nilsen, P., Nordström, G., Ellström, P.-E. (2012), Integrating researchbased and practice-based knowledge through workplace reflection, Journal of Workplace Learning, 24(6), 403-15.

Nilsen P., et al. (2012), Creatures of habit: accounting for the role of habit in implementation research on clinical behaviour change, Implementation Science, 7 (53).

Nonaka, I., Takeuchi, H. (1995), The knowledge-creating company: how Japanese companies create the dynamics of innovation (Oxford: Oxford University Press).

Nutley, S.M., Walter, I., Davies, H.T.O. (2007), Using evidence: how research can inform public services (Bristol: The Policy Press).

O'Brien, D. (2006), An introduction to the theory of knowledge (Cambridge, UK: Polity Press).

Olsson, T.M. (2007), Reconstructing evidence-based practice: an investigation of three conceptualisations of EBP, Evidence \& Policy, 3, 27185 .

Patton, M.Q. (2002), Qualitative research \& evaluation methods (3rd edn.) (London: Sage).

Pispati, P.K. (2003), Evidence-based practice in rheumatology, APLAR Journal of Rheumatology, 6(1), 44-9.

Polyani, M. (1983), The tacit dimension (New York: Doubleday).

Pressman, J.L., Wildavsky, A.B. (1973), Implementation: how great expectations in Washington are dashed in Oakland. Or: Why it's amazing that Federal programs work at all, this being a saga of the Economic Development Administration as told by two sympathetic observers who seek to build morals on a foundation of ruined hopes (Berkeley, CA: University of California Press). 
Proctor, E., et al. (2011), Outcomes for implementation research: conceptual distinctions, measurement challenges, and research agenda, $A d-$ ministration and Policy in Mental Health, 38, 65-76.

Ramos-Morcillo, A.J., et al. (2015), Effectiveness of a brief, basic evidencebased practice course for clinical nurses, Worldviews on EvidenceBased Nursing, 12, 199-207.

Reichenpfader, U., Carlfjord, S., Nilsen, P. (2015), Leadership in evidencebased practice: a systematic review, Leadership in Health Services, 28(4), 298-316.

Revenäs, Å., et al. (2015), Development of a web-based and mobile app to support physical activity in individuals with rheumatoid arthritis: results from the second step of a co-design process, JMIR Research Protocols, 9(4(1)), e22.

Rogers, E.M. (2003), Diffusion of innovations (New York: Free Press).

Rycroft-Malone, J., Bucknall, T. (2010), Models and frameworks for implementing evidence-based practice (Chichester: Wiley-Blackwell).

Sackett, D.I., et al. (1996), Evidence based medicine: what it is and what it isn't, $B M J, 312(7023), 71-2$.

Satterfield, J.M., et al. (2009), Toward a transdisciplinary model of evidence-based practice, The Milbank Quarterly, 87(2), 368-90.

Schein, E.H. (2010), Organizational culture and leadership (4th edn) (San Francisco, CA: Jossey-Bass).

Schneider, B, et al. (2005), Understanding organization-customer links in service settings, The Academy of Management Journal, 48, 1017-32.

Scott-Findlay, S., Estabrooks, C.A. (2006), Mapping the research utilization field in nursing, Journal of Advanced Nursing, 56(5), 498-513.

Sigma Theta Tau International Evidence-based Practice Task Force (2004), Evidence-based nursing: rationale and resources, Worldviews on Evidence-Based Nursing, 1, 69-75.

Socialstyrelsen (2016), The national guidelines for musculoskeletal diseases - summary (Stockholm).

Sohoran, E. (1993), We do, therefore we learn, Training and Development, 4, 47-52.

Sokka, T., et al. (2013), Similar clinical outcomes in rheumatoid arthritis with more versus less expensive treatment strategies. Observational data from two rheumatology clinics, Clinical and Experimental Rheumatology, 31 (3), 409-14.

Squires, J.E., Moralejo, D., Lefort, S.M. (2007), Exploring the role of organizational policies and procedures in promoting research utilization in registered nurses, Implementation Science, 2, 17.

Squires, J.E., et al. (2011a), Individual determinants of research utilization by nurses: a systematic review update, Implementation Science, 6, 1.

Squires, J.E., et al. (2011b), A systematic review of the psychometric properties of self-report research utilization measures used in healthcare, Implementation Science, 6(1), 1-18.

SRQ (2015), The Swedish Rheumatology Quality Register. 
Stetler, C.B., et al. (2011), A guide for applying a revised version of the PARIHS framework for implementation, Implementation Science, 6, 99.

Stokke, K., et al. (2014), Evidence based practice beliefs and implementation among nurses: a cross-sectional study, BMC Nursing, 13(1), 8.

Straus, S.E. (2007), Evidence-based health care: challenges and limitations, Evidence-Based Communication Assessment and Intervention, 1(1), 48-51.

Straus, S., Haynes, B. (2009), Managing evidence-based knowledge: the need for reliable, relevant and readable resources, CMAJ 180(9), 942-45.

Straus, S., Tetroe, J., Graham, I.D. (2009), Knowledge translation in health care - moving from evidence to practice (Oxford: Blackwell Publishing).

Straus, S.E., McAlister, A. (2000), Evidence-based medicine: a commentary on common criticisms, CMAJ, 163(7), 837-41.

Swedish Rheumatism Association (2016). https://reumatikerforbundet.org/om-oss/about-swedish-rheumatism-association/. Accessed Feb 17.

Svensson, L., Ellström, P.-E., Åberg, C. (2004), Integrating formal and informal learning at work, Journal of Workplace Learning, 16(8), 47991.

Taylor, S.L., et al. (2011), What context features might be important determinants of the effectiveness of patient safety practice interventions?, BMJ Quality \& Safety, 20(7), 611-17.

Thorne, S., Sawatsky, R. (2014), Particularizing the general. Sustaining theoretical integrity in the context of an evidence-based practice agenda, Advances in Nursing Science, 37(1), 5-18.

Thyberg, I., et al. (2012), Potential of the HAQ score as clinical indicator for multi-professional interventions: the Swedish TIRA cohort 8 years after diagnosis of RA, Clinical Rheumatology, 31, 775-83.

Tilson, J.K., et al. (2011), 'Sicily statement on classification and development of evidence-based practice learning assessment tools.', BMC Medical Education, 11 (78).

Trinder, L. (2000), A critical appraisal of evidence-based practice, in L. Trinder, S. Reynolds (eds.), Evidence-based practice - a critical appraisal (Oxford: Blackwell Science).

van Vollenhoven, R.F., et al. (2012), Conventional combination treatment versus biological treatment in methotrexate-refractory early rheumatoid arthritis: 2 year follow-up of the randomised, non-blinded, parallel-group Swefot trial, The Lancet 379(9827), 1712-20.

Weiss, C. (1979), The many meanings of research utilization, Public Administration Review 1979(39), 426-31.

Wenger, E. (1998), Communities of practice: learning, meaning and identity (New York: Cambridge University Press). 
Verschueren, P., Westhovens, R. (2011), Optimal care for early RA patients: the challenge of translating scientific data into clinical practice, Rheumatology (Oxford), 50(7), 1194-200.

Wolfe, F., Michaud, K. (2010), The loss of health status in rheumatoid arthritis and the effect of biologic therapy: a longitudinal observational study, Arthritis Research \& Therapy 12, R35.

Woolf, A.D. (2007), Healthcare services for those with musculoskeletal conditions: a rheumatology service. Recommendations of the European Union of Medical Specialists Section of Rheumatology/European Board of Rheumatology 2006, Annals of the Rheumatic Diseases, 66(3), 293-301.

World Health Organization (2001), International classification of function, disability and health: ICF (Geneva: WHO).

Yost, J., Dobbins, M., Ciliska, D. (2014), Evaluating the impact of an intensive education workshop on evidence-informed decision making knowledge, skills, and behaviours: a mixed methods study, $B M C$ Medical Education, 14(13), 1-9.

Yost, J., et al. (2015), The effectiveness of knowledge translation interventions for promoting evidence-informed decision-making among nurses in tertiary care: a systematic review and meta-analysis, Implementation Science, 10, 98.

Yukl, G. (2005), Leadership in organisations (6th edn.) (Upper Saddle River, NJ: Pearson Education).

Zangi, H.A., et al. (2012), A mindfulness-based group intervention to reduce psychological distress and fatigue in patients with inflammatory rheumatic joint diseases: a randomised controlled trial, Annals of the Rheumatic Diseases, 71(6), 911-17. 


\section{APPENDIX}

Interview guide in the qualitative dat collection.

1. Har du nyligen ställts inför en uppgift $i$ arbetet som utmanade din kompetens? (Hur gjorde du då?)

2. Har du nyligen infört något nytt $i$ arbetet? Börjat arbeta annorlunda eller göra nya moment? Finns det saker som du gör i ditt arbete idag, som du inte kunde göra för några år sedan? Hur lärde du dig detta?

3. Vilken möjlighet till lärande och utveckling erbjuder ditt arbete? Vem lär du dig mest av på kliniken? I vilka situationer?

4. Hur använder du din erfarenhet $i$ din yrkesutövning? Kan du ge ett exempel på när du hade hjälp av din erfarenhet i yrket? Har du kunnat hjälpa kollegor med din erfarenhet eller själv kunnat dra nytta av deras erfarenhet?

5. Finns det utbildningar eller kurser som har påverkat dig mycket $i$ ditt dagliga arbete? Kan du ge exempel? Hur det gått att sprida den kunskapen?

Har du möjligheter att diskutera kring ny kunskap (erfarenhet eller forskningsresultat) med dina arbetskamrater? Inom yrket? Med andra professioner på kliniken? Med patienter?

6. Vilken roll upplever du att forskningsresultat spelar i ditt kliniska vardagsarbete? Kan du ge ett exempel på när du hade hjälp av forskningsresultat i yrket? Har du kunnat hjälpa kollegor med din kunskap från forskningsresultat? Finns det saker som ni gör mindre av nu, eller slutat med på grund av ny kunskap?

7. Har du kontakter i yrket utanför kliniken?

På vilket sätt kommunicerar ni med varandra? Hur ofta?

8. Hur skulle ditt yrkesrelaterade lärande kunna stödjas? Hur ser du på ditt eget ansvar, arbetsgruppens, chefens ansvar för lärandet?

9. Finns det något som du skulle vilja lägga till utöver det som vi har pratat om? 



\section{Papers}

The articles associated with this thesis have been removed for copyright reasons. For more details about these see:

http://urn.kb.se/resolve?urn=urn:nbn:se:liu:diva-127495 